\title{
Research on green supply chain: A bibliometric analysis
}

Keivan Amirbagheri ${ }^{1}$, Ana Núñez-Carballosa ${ }^{1}$, Laura Guitart-Tarrés ${ }^{1}$, José M. Merigó ${ }^{2,3}$

${ }^{1}$ Department of Economics and Business, Faculty of Economics and Business, University of Barcelona, Av. Diagonal 690, 08034 Barcelona, Spain

${ }^{2}$ Department of Management Control and Information Systems, School of Economics and Business, University of Chile, Av. Diagonal Paraguay 257, 8330015 Santiago, Chile

${ }^{3}$ School of Systems, Management and Leadership, Faculty of Engineering and Information Technology, University of Technology Sydney, 81 Broadway, Ultimo 2007, NSW, Australia 


\begin{abstract}
Recently, the emergent concept of green supply chain has received increasing attention. Although popular among scholars, many literature reviews have only examined GSC from a general point of view or focused on a specific issue related to GSC. This study presents a comprehensive analysis of the influence and productivity of research on GSC from 1995 to 2017 by reporting trends among authors, countries and institutions based on a bibliometric approach. To this end, the study analyses around 1900 papers on GSC. This study uses the Web of Science Core Collection database to analyze the bibliometric data and the visualization of similarities (VOS) viewer method to graphically map that data. The graphical analysis uses bibliographic coupling, co-citation, co-authorship and co-occurrence of keywords.
\end{abstract}

Keywords: Green supply chain, bibliometric approach, Web of science, VOS viewer

\title{
1. Introduction
}

Over the last decades, enterprises have begun to apply environmental management programs, and, green supply chain practices, to help them compete in the markets. At the same time, the number of studies on green supply chain (GSC) has significantly increased during this period.

Numerous studies have reviewed the literature on GSC in the period surveyed in this study. Each of these works has analyzed the GSC literature from a different point of view. For example, Srivastava (2007) adopts an integrated and fresh approach to consider the field of green supply chain management (GSCM) because of the necessity to present a comprehensive references of GSCM to help academicians, researchers and practitioners. Carter and Rogers (2008) provide a large-scale literature review and use conceptual theory to introduce the concept of sustainability to the field of supply chain management. They demonstrate the relationships among environmental, social, and economic performance within the context of a supply 
chain management. Seuring and Müller (2008) offer a conceptual framework to summarize the research in the field of sustainable supply chain. Their paper also offers a literature review on sustainable supply chain management. Hassini et al. (2012) review the literature related to sustainable supply chain (SSC) and provide a framework for SSC and performance management, whereas Ahi and Searcy (2013) identify and analyze the published definitions of GSCM and sustainable supply chain management (SSCM). Tiwari et al. (2018) analyze big data analytics in supply chain management. On the other hand, Govindan et al. (2015) focus on green supplier selection, whereas Miemczyk et al. (2012) investigate the sustainability of a purchasing and supply chain. Fahimnia et al. (2015) present a comprehensive evolution of the field, focusing on forward green supply chain practices by implementing a bibliometric methodology. Although, the abovementioned literature review as well as other works, provides valuable information on the state of the literature on GSC, there is still much need for a comprehensive bibliometric approach to analyze this literature. Based on this reality, after 2012 that is the last year of the work by Fahimnia et al. (2015) the GSC area experience a huge increasing trend so our study tries to cover this growth and report it. Besides, we believe that Web of Science (WoS) as a comprehensive database could prepare more complete results that can help us to obtain a more thorough analysis of this area. Also, in our work the items not only from one aspect (No. of papers) but also based on many measurements such as total publications, total citation and $h$ index try to explore the trends and the different items.

The aim of the work is to provide a bibliometric overview of GSC by using a modern bibliometric approach that uses several bibliometric indicators and the VOS viewer software during a 22-year period from 1995 to 2017 by reporting trends among authors, countries and institutions. To present the results graphically, this paper uses VOS viewer software (Van Eck 
and Waltman 2010). To develop the mapping analysis, this study uses bibliographic coupling (Kessler 1963), co-citation (Small 1973), co-authorship and co-occurrence of keywords (Merigó et al. 2016).

This paper first briefly discusses concepts and bibliometric studies related to green supply chain and reviews the existing literature. The next section describes the bibliometric methods used throughout the paper. Section 4 presents the bibliometric results of the WoS Core Collection, and Section 5 develops a graphical analysis of the bibliographic materials. The closing section describes the paper's findings and states its conclusions.

\section{Background}

\subsection{Green supply chain}

An important environmental concept that has gained attention among companies and scholars over recent decades is GSCM. At the same time, a diverse set of definitions has been suggested for GSCM. This concept, as Srivastava (2007) notes, can be defined in several ways such as green purchasing, integrated green supply chains flowing from supplier to manufacturer to customer, or reverse logistics. As mentioned above, Ahi and Searcy (2013) propose a thorough framework of 22 definitions of GSCM and 12 definitions of SSCM. Tseng et al. (2016) present empirical evidence of firms' GSC capabilities while Tsireme et al. (2012) explore the reasons that affect the decisions of managers of firms to adopt management practices in order to GSCM. The main objective of GSCM is to reduce, as much as possible, harmful environmental influences such as air and water pollution and to improve the ability to manage waste of resources such as energy, materials and products (Rao and Holt 2005; Eltayeb et al. 2011).

Many studies conduct to achieve these objectives. For instance, Sarkis (2012) provides a framework to understand and appreciate the relationships among various research streams and 
topics in the field. Kainuma and Tawara (2006), extend the scope of supply chains to include reuse and recycling of products and services throughout their life cycle and applied that extended notion in a setting to confirm its efficiency. Based on their technique, Kainuma and Tawara (2006) were able to measure environmental and managerial performance. In another study, Kumar et al. (2012) explore a simple model that companies may use to understand and improve supply chain sustainability practices. Besides, de Oliviera et al. (2018) present the GSCM practices from a comprehensive point of view and to analyze the subject's behavior through a bibliometric analysis from 2006 to 2016.

\subsection{Antecedents}

There are numerous definitions for the term bibliometrics in the literature. One of the very first definitions of this term, provided by Pritchard (1969) is "the application of mathematics and statistical methods to books and other media communications". A more comprehensive definition, suggested by White and Mccain $(\underline{1989})$ is that "bibliometrics is the quantitative study of the literature as they are reflected in bibliographies." According to yet another definition, proposed by Broadus (1987) bibliometrics is "the quantitative study of physical published units, or of bibliographic units, or of surrogates of either" (Hood and Wilson 2001). The power of bibliometrics to classify the various aspects of a publication and its reported results in an organized form, made bibliometrics a popular method. Additionally, this methodology is possible to apply not only in all of the fields of science but also can be used to review the performance of different journals (Laengle et al. 2018; Martínez-López et al. 2018). By using a very powerful and multifunctional software, it is easy to analyze the results obtained through bibliometrics (Merigó et al. 2015). The traces of a bibliometric analysis can be detected in papers in operational research/management science (OR/MS), production and operational management 
(POM), supply chain management (SCM), green supply chain (GSC) and some other environmental science disciplines.

In recent decades, the use of OR/MS within the scientific community has increased substantially (Merigó and Yang 2017). They present a bibliometric overview of research published in OR/MS to identify some of the most relevant studies in this field and some of the newest trends according to the information found in the Web of Science database. Chang and Hsieh (2008) evaluate the distribution of papers published by Asian authors in OR/MS journals from 1968 to 2006 based on a bibliometric analysis, whereas White et al. (2011) attempt to present an overall assessment of OR in developing countries. In another work, Mingers and $\mathrm{Xu}$ (2010) have concentrated on citation counts of papers published in six well-known MS journals.

"The origin of operations management is closely linked with the birth of the company itself, as there has always been a need to produce goods and services to be managed" (Alfalla-Luque and Medina-López 2009). Several bibliometric studies have also been done in the field of POM. Pilkington and Liston-Heyes (1999) use a co-citations analysis to investigate the intellectual foundations of the POM literature and consider whether they are distinct from those commonly associated with rival fields. Hsieh and Chang (2009) based on papers published in 20 core POM journals, explore the global POM research. Moreover, most of the academic areas of management have performed studies based on bibliometric parameters. These areas range from accounting and business to technologies used in business and industry.

Supply chain management is a strategy for integrating the activities of a supply chain (Oliver and Webber 1982) on a day by day basis, which has gained popularity among academics, and its nature has been investigated in numerous studies (Shiau et al. 2015). For example, Wong et al. (2012) develop a systematic review of the cross-disciplinary literature on SCM. At the same 
time, numerous studies analyze supply chain management through a bibliometric perspective. Charvet et al. (2008) use a bibliometric approach to study the intellectual structure of supply chain management. In another work, Alfalla-Luque and Medina-López (2009) examine SCM and its influence on the needs of companies by analyzing the bibliometric studies of the main journals in the discipline. Also, Chen et al. (2017) conduct a systematic literature review and a quantitative bibliometric analysis to review the literature to find out about the items that are studied by the authors and the existing gaps in the body of knowledge.

Some of the bibliometric studies focus on specific issues of GSC such as performance measurement (Beske-Janssen et al. 2015), corporate social responsibility for supply chain management (Feng et al. 2017) or green innovation (Albort-Morant et al. 2017). For example, Fahimnia et al. (2015) present a comprehensive evolution of the field, focusing on forward green supply chain practices by implementing a bibliometric methodology; their findings provide a robust roadmap for further investigations in this field. Beske-Janssen et al. (2015) systematically review the academic literature on sustainability performance measurement for SSCM published in the last 20 years. In the other study Thome et al. (2016) offer a novel combination of systematic literature review and bibliometric analysis of sustainable new product development.

There are some bibliometric works that have done to study some environmental issues. As an example, Hu et al. (2010) did a bibliometric analysis to identify the global research related to lead in drinking water field from 1991 to 2007 or in another similar work, (Fu et al. 2013) analyzed the same topic but during 1992 and 2011. Zhao et al. (2018) has conducted a largescale bibliometric analysis on the trends of the emerging contaminants, Nano adsorbents, Nano photocatalysts, and related research topics from the literature during 1998-2017. In another study, Wang et al. (2014) have carried out a bibliometric analysis to provide insights into 
research activities and tendencies of the global risk of engineering nanomaterials (ENMs) from 1999 to 2012. From the other point of view, Andrade et al. (2017) have organized a bibliometric analysis to investigate and analyze the scientific production related to indoor air quality of environments used for physical exercise and sports practice. Ioana-Toroimac (2018) through a review of previous publications builds maps of scientific knowledge on the hydromorphology integration in the water framework directive. In a more general and comprehensive perspective, (Khan and Ho 2012) identified the top-cited articles published in environmental science journals listed in Journal Citation Reports (JCR). Finally, (Dragos and Dragos 2013) with a help of bibliometric approach, analyze the factors affecting scientific productivity in environmental sciences and ecology.

\section{Bibliometric methods}

This study uses certain bibliometric indicators to organize the data in a more reader-friendly form. By implementing these indicators, the paper aims to show different results relating to the same variable (Cancino et al. 2017). Among other things, the study uses the total number of papers and citations to measure productivity and influence, cites per paper and $h$-index (Alonso et al. 2009; Hirsch 2005). In addition, the study uses citation thresholds and some other indicators such as institutions ranking, country ranking, and publications per person (Laengle et al. 2017; Valenzuela et al. 2017).

The study provides the bibliometric data from WoS Core Collection database. The search process occurred in September 2017 by using the keyword "green and supply chain". Search results are for articles published by the end of 2017. The initial search identified 2440 papers which was later reduced to 1892 after removing any paper other an article, a review, a letter or a 
note. So, the final number of papers of the analysis is 1892 . The documents have 58785 citations in total resulting in 31.07 citation-per-paper. The $h$-index is 111 , implying that out of the 1892 papers, 111 have 111 citations or more.

As a complementary analysis, this study also presents a graphical image of the bibliographic material using the VOS viewer software (Van Eck and Waltman 2010). This software collects data and generates maps based on bibliographic coupling, co-authorship, citation, co-citation and co-occurrence of keywords (Merigó et al. 2016). Bibliographic coupling (Kessler 1963) occurs when two papers cite the same third paper. Co-citation (Small 1973) measures the most cited paper; it occurs when two papers are cited by a third paper. Co-authorship measures the degree of co-authorship of the most productive authors. Citation analysis focuses on the degree of citations between two variables. The co-occurrence of keywords shows the most common keywords used by different papers, as well as which keywords usually appear below the abstract. Network connection visualizes the keywords that appear more frequently in the same papers (Cancino et al. 2017).

\section{Results}

\subsection{Publication and citation structure of GSC}

The very first paper on GSC was published in 1995. Since then, the number of papers published on GSC has grown. To better understand this trend, Table 1 reports the number of papers published on GSC and their total citations. Additionally, by defining some thresholds, Table 1 identifies the range of highly cited papers relative to those with one or five citations. 
During the first seven years of the period studied in this paper, the number of papers published on GSC had not exceeded one. After this period, there had been a slight growth in the number of papers- published on GSC. Until 2012, the number of published papers had increased significantly relative to previous years. From 2012 to 2017, journals had published increasingly more papers; the highest number of published papers is in 2017 with 469 papers. It should be noted that $6.82 \%$ of the papers have received more than one hundred citations; that is 129 out of 1892 papers. In addition, $15.54 \%$ of the papers have received more than fifty citations and $68.08 \%$ and $90.17 \%$ of the papers have received more than five and one citations, respectively.

The next step is to analyze the most cited published papers in various journals. Table $\underline{2}$ reports the results based on a list of the fifty most cited papers of all time. The most cited paper in the GSC area was published in 2008 by Stefan Seuring and Martin Mueller; this paper has received one thousand four hundred citations. Among the ten most cited papers, Joseph Sarkis and Qinghua Zhu are leading the list with three and two papers, respectively.

Another interesting item involving several factors, is the most cited papers by other papers published in the GSC field. To derive this output, this study applies the VOS viewer (Van Eck and Waltman, 2010) which enabled us to generate the results for co-citation of papers. Table $\underline{3}$ shows the thirty most cited papers from the highest to the lowest. The first three papers on this list receive the highest number of citations among the papers listed in Table $\underline{2}$.

In addition, another interesting item is the journals that are citing GSC. Table $\underline{4}$ presents the thirty journals that publish the largest numbers of papers citing GSC. To gain a deeper insight into these results, we have divided them into four periods. The first period stretches from 1995 to 2002 and the last from 2013 to 2017. Journal of Cleaner Production is the leading journal on this 
list. In the last two periods (from 2008 to 2017) there has been a sharp increase in the number of published papers citing GSC. Interestingly the third-ranked journal on this list Sustainability, which has published 30 papers during the last five years.

A valuable point of view is obtained by data on authors, universities and countries of papers citing GSC. This analysis provided us with essential information about the GSC literature. Table 5 shows the Top 30. After Clarck university the next two universities are Asians universities: the Hong Kong Polytechnic university and Dalian university of technology. The presence of a remarkable number of Asian universities among the top universities, shows the high interest in GSC in this region. Besides, the presence of many Asian countries in the analysis of countries also indicates the importance of this research area in Asia. Note that in this table and the other ones, form on side we considered China and Taiwan as one country and form the other side we also report them as separated ones.

\subsection{Leading institutions and countries of GSC}

Table $\underline{6}$ reports valuable information about the active institutions in the field of GSC. This table was organized based on the largest number of papers published in the journal. In addition, this comprehensive source shows some valuable information such as cites per paper, $h$-index, and number of papers in each journal among the Top 50 most cited articles.

The Hong Kong Polytechnic University is the most productive and influential institute on this list. Because the ranking is based on the level of productivity, some universities, such as the Dalian University of Technology have a higher level of influence and a lower level of productivity than other institutions. Thus, although the Dalian University of Technology is ranked third, it has more citations relative to the University of Southern Denmark. 
With the help of Table $\underline{7}$ it is possible to consider a more detailed view of the institutions during the period surveyed in this paper. According to the information shown in these tables, although a Danish university is the leader of the last period of this study, but the presence of Asian universities and especially the Chinese one is an important fact. The vital message folded in these data is the presence of Asian universities among the top universities; for example, the Islamic Azad university is the fourth one or university of Tehran that is seventh university of the list in the last period of the study.

Table $\underline{8}$ which reports results on countries, provides a general understanding of these results and some important general criteria and represents the same results through five-year intervals. The USA in both the general and the five-year interval formats occupies the first position if we don't consider China and Taiwan as a same country. However, the table shows a rapid ascent of Asian countries to the top of the list. Moreover, additional changes in the ranking of countries seem to be inevitable.

\section{Graphical analysis of GSC with VOS viewer}

The previous part focused on general results concerning leadings authors, institutions and countries in the field of GSC. It is also useful, however, to examine such outputs as co-citation and co-occurrence of keywords. To this end, this study uses VOS viewer software (Van Eck and Waltman 2010).

To show co-citation, that is, two journals cited by a third journal, Figure 1 reports the results of journals with a threshold of one hundred citations and of papers with the one hundred most representative co-citation connections. As it can be seen, different clusters of journals are separated by distinct colors that Journal of Cleaner Production is in the center of this figure that 
shows as a leading journal among various journals that publish papers in GSC has the highest rate of receiving citations from the others. Besides, another interesting item is the form of the dispersion of the journals. Normally, the clusters are formed based on the common subjects in the same area and cite the journals that are in their area although there are some exceptions also.

Table 1

Annual citation structure of GSC

\begin{tabular}{ccccccccc}
\hline Year & TP & TC & $\geq 100$ & $\geq 50$ & $\geq 20$ & $\geq 10$ & $\geq 5$ & $\geq 1$ \\
\hline 1995 & 1 & 21 & 0 & 0 & 1 & 1 & 1 & 1 \\
1996 & 1 & 300 & 1 & 1 & 1 & 1 & 1 & 1 \\
1997 & 2 & 80 & 0 & 1 & 2 & 2 & 2 & 2 \\
1998 & 1 & 244 & 1 & 1 & 1 & 1 & 1 & 1 \\
1999 & 0 & 0 & 0 & 0 & 0 & 0 & 0 & 0 \\
2000 & 3 & 235 & 1 & 1 & 2 & 2 & 2 & 3 \\
2001 & 1 & 69 & 0 & 1 & 1 & 1 & 1 & 1 \\
2002 & 6 & 620 & 2 & 2 & 4 & 5 & 6 & 6 \\
2003 & 4 & 809 & 2 & 2 & 4 & 4 & 4 & 4 \\
2004 & 11 & 1360 & 3 & 6 & 8 & 10 & 11 & 11 \\
2005 & 10 & 2362 & 5 & 8 & 10 & 10 & 10 & 10 \\
2006 & 9 & 1604 & 7 & 9 & 9 & 9 & 9 & 9 \\
2007 & 20 & 3870 & 12 & 16 & 17 & 20 & 20 & 20 \\
2008 & 35 & 5559 & 16 & 22 & 29 & 32 & 33 & 34 \\
2009 & 30 & 2572 & 8 & 18 & 24 & 28 & 29 & 29 \\
2010 & 69 & 3631 & 13 & 25 & 40 & 56 & 60 & 67 \\
2011 & 81 & 5884 & 19 & 43 & 55 & 65 & 72 & 78 \\
2012 & 150 & 7203 & 18 & 51 & 103 & 120 & 137 & 148 \\
2013 & 141 & 5830 & 13 & 36 & 88 & 113 & 126 & 137 \\
2014 & 206 & 5811 & 6 & 30 & 101 & 148 & 180 & 199 \\
2015 & 283 & 5235 & 2 & 19 & 99 & 170 & 214 & 267 \\
2016 & 359 & 3288 & 0 & 1 & 50 & 120 & 218 & 328 \\
2017 & 469 & 2198 & 0 & 1 & 17 & 70 & 151 & 350 \\
Total & 1892 & 58785 & 129 & 294 & 666 & 988 & 1288 & 1706 \\
$\%$ & $100 \%$ & & $6.82 \%$ & $15.54 \%$ & $35.20 \%$ & $52.22 \%$ & $68.08 \%$ & $90.17 \%$ \\
\hline A & $1965 \%$
\end{tabular}

Abbreviations: TP and Tc $=$ Total papers and citations; $\geq 100, \geq 50, \geq 20, \geq 10, \geq 5, \geq 1$ Number of papers with equal or more $100,50,20,10,5$ and 1 citations 
Table2

\begin{tabular}{|c|c|c|c|c|c|c|}
\hline $\mathrm{R}$ & Journal & $\mathrm{TC}$ & Title & Author/s & Year & $\mathrm{C} / \mathrm{Y}$ \\
\hline 1 & $\mathrm{JCP}$ & 1400 & $\begin{array}{l}\text { From a literature review to a conceptual framework for sustainable supply chain } \\
\text { management }\end{array}$ & Seuring, S; Mueller, M & 2008 & 140 \\
\hline 2 & IJMR & 1079 & Green supply-chain management: A state-of-the-art literature review & Srivastava, SK & 2007 & 98.09 \\
\hline 3 & IJPDL & 825 & A framework of sustainable supply chain management: moving toward new theory & Carter, CR.; Rogers, DS & 2008 & 82.50 \\
\hline 4 & JOM & 783 & $\begin{array}{l}\text { Relationships between operational practices and performance among early adopters of } \\
\text { green supply chain management practices in Chinese manufacturing enterprises }\end{array}$ & Zhu, QH; Sarkis, J & 2004 & 55.93 \\
\hline 5 & IJOPM & 670 & Do green supply chains lead to competitiveness and economic performance? & Rao, P; Holt, D & 2005 & 51.54 \\
\hline 6 & POM & 569 & Sustainable operations management & $\begin{array}{l}\text { Kleindorf, PR; Singhal, K; Van } \\
\text { Wassenhove, LN }\end{array}$ & 2005 & 43.77 \\
\hline 7 & JOM & 558 & Sustainable supply chains: An introduction & $\begin{array}{l}\text { Linton, JD.; Klassen, RD; Jayaraman, } \\
\text { V }\end{array}$ & 2007 & 50.73 \\
\hline 8 & $\mathrm{JCP}$ & 529 & A strategic decision framework for green supply chain management & Sarkis, J & 2003 & 35.27 \\
\hline 9 & IJPE & 504 & An organizational theoretic review of green supply chain management literature & Sarkis, J; Zhu, QH; Lai, KH & 2011 & 72 \\
\hline 10 & IJPE & 491 & $\begin{array}{l}\text { Environmental management and manufacturing performance: The role of collaboration in } \\
\text { the supply chain }\end{array}$ & Vachon, S; Klassen, RD & 2008 & 49.10 \\
\hline 11 & IJOPM & 471 & $\begin{array}{l}\text { Extending green practices across the supply chain - The impact of upstream and } \\
\text { downstream integration }\end{array}$ & Vachon, S; Klassen, RD & 2006 & 39.25 \\
\hline 12 & JSCM & 423 & $\begin{array}{l}\text { Building a more complete theory of sustainable supply chain management using case } \\
\text { studies of } 10 \text { examples }\end{array}$ & Pagell, M; Wu, Z & 2009 & 47 \\
\hline 13 & IJOPM & 409 & Green supply chain management in China: Pressures, practices and performance & Zhu, QH; Sarkis, J; Geng, Y & 2005 & 31.46 \\
\hline 14 & IJPE & 375 & $\begin{array}{l}\text { Confirmation of a measurement model for green supply chain management practices } \\
\text { implementation }\end{array}$ & Zhu, QH; Sarkis, J; Lai, KH & 2008 & 37.50 \\
\hline 15 & IJPDL & 360 & Sustainable supply chain management: evolution and future directions & Carter, CR.; Easton, PL & 2011 & 51.43 \\
\hline 16 & $\mathrm{JCP}$ & 354 & $\begin{array}{l}\text { Green supply chain management: pressures, practices and performance within the Chinese } \\
\text { automobile industry }\end{array}$ & Zhu, QH; Sarkis, J; Lai, KH & 2007 & 32.18 \\
\hline 17 & $\mathrm{JCP}$ & 300 & $\begin{array}{l}\text { An inter-sectoral comparison of green supply chain management in China: Drivers and } \\
\text { practices }\end{array}$ & Zhu, QH; Sarkis, J & 2006 & 25.00 \\
\hline 18 & CMR & 300 & Lean and green: The move to environmentally conscious manufacturing & Florida, R & 1996 & 13.64 \\
\hline 19 & IJPR & 292 & $\begin{array}{l}\text { The moderating effects of institutional pressures on emergent green supply chain practices } \\
\text { and performance }\end{array}$ & Zhu, QH; Sarkis, J & 2007 & 26.55 \\
\hline 20 & DSS & 288 & A review of modeling approaches for sustainable supply chain management & Seuring, $\mathrm{S}$ & 2013 & 57.60 \\
\hline 21 & IJOPM & 285 & Greening the supply chain: a new initiative in South East Asia & Rao, $\mathrm{P}$ & 2002 & 17.81 \\
\hline 22 & EJOR & 284 & $\begin{array}{l}\text { Quantitative models for sustainable supply chain management: Developments and } \\
\text { directions }\end{array}$ & $\begin{array}{l}\text { Brandenburg, M; Govindan, K; Sarkis, } \\
\text { J; Seuring, S }\end{array}$ & 2014 & 71 \\
\hline 23 & IJPE & 266 & A literature review and a case study of sustainable supply chains with a focus on metrics & Hassini, Elkafi; S, Chirag; SC & 2012 & 44.33 \\
\hline
\end{tabular}


Table 2 (continued)

\begin{tabular}{|c|c|c|c|c|c|c|}
\hline $\mathrm{R}$ & Journal & $\mathrm{TC}$ & Title & Author/s & Year & $\mathrm{C} / \mathrm{Y}$ \\
\hline 24 & ESA & 262 & $\begin{array}{l}\text { A novel hybrid MCDM approach based on fuzzy DEMATEL, fuzzy ANP and fuzzy } \\
\text { TOPSIS to evaluate green suppliers }\end{array}$ & Buyukozkan, G; Cifci, G & 2012 & 43.67 \\
\hline 25 & IJPE & 260 & $\begin{array}{l}\text { Impact of lean manufacturing and environmental management on business } \\
\text { performance: An empirical study of manufacturing firms }\end{array}$ & Yang, MG; Hong, P; Modi, SB & 2011 & 37.14 \\
\hline 26 & $\mathrm{JCP}$ & 257 & $\begin{array}{l}\text { Mapping the green product development field: engineering, policy and business } \\
\text { perspectives }\end{array}$ & Baumann, H; Boons, F; Bragd, A & 2002 & 16.06 \\
\hline 27 & RCR & 255 & $\begin{array}{l}\text { An analysis of the drivers affecting the implementation of green supply chain } \\
\text { management }\end{array}$ & Diabat, A; Govindan, $\mathrm{K}$ & 2011 & 36.43 \\
\hline 28 & ESA & 253 & A green supplier selection model for high-tech industry & $\begin{array}{l}\text { Lee, AHI; Kang, HY; Hsu, CF; } \\
\text { et al. }\end{array}$ & 2009 & 28.11 \\
\hline 29 & MQ & 248 & Information systems innovation for environmental sustainability & Melville, NP & 2010 & 31 \\
\hline 30 & EJOR & 246 & $\begin{array}{l}\text { Operations Research for green logistics - An overview of aspects, issues, } \\
\text { contributions and challenges }\end{array}$ & Dekker, R; Bloemhof, J; Mallidis, I & 2012 & 41 \\
\hline 31 & EJOR & 244 & Evaluating environmentally conscious business practices & Sarkis, J & 1998 & 12.20 \\
\hline 32 & $\mathrm{JCP}$ & 224 & $\begin{array}{l}\text { A comparative literature analysis of definitions for green and sustainable supply } \\
\text { chain management }\end{array}$ & Ahi, P; Searcy, C & 2013 & 44.80 \\
\hline 33 & TRE & 224 & An integrated logistics operational model for green-supply chain management & Sheu, JB; Chou, YH; Hu, CC & 2005 & 17.23 \\
\hline 34 & OIJMS & 223 & Network design for reverse logistics & Srivastava, SK & 2008 & 22.30 \\
\hline 35 & POM & 220 & $\begin{array}{l}\text { Collaboration and evaluation in the supply chain: The impact on plant-level } \\
\text { environmental investment }\end{array}$ & Klassen, RD; Vachon, S & 2003 & 14.67 \\
\hline 36 & DSS & 216 & A multi-objective optimization for green supply chain network design & Wang, F; Lai, X; Shi, N & 2011 & 30.86 \\
\hline 37 & TRE & 215 & Green supply chain management implications for closing the loop & Zhu, QH; Sarkis, J; Lai, KH & 2008 & 21.50 \\
\hline 38 & IJPE & 212 & Modeling carbon footprints across the supply chain & $\begin{array}{l}\text { Sundarakani, B; de Souza, R; Goh, } \\
\text { M; Wagner, SM; Manikandan, S }\end{array}$ & 2010 & 26.50 \\
\hline 39 & SCMIJ & 212 & Corporate social responsibility in global supply chains & Andersen, M; Skjoett-Larsen, T & 2009 & 23.56 \\
\hline 40 & TRE & 209 & Environmental purchasing and firm performance: an empirical investigation & Carter, CR; Kale, R; Grimm, CM & 2000 & 11.61 \\
\hline
\end{tabular}


Table 2 (continued)

\begin{tabular}{|c|c|c|c|c|c|c|}
\hline $\mathrm{R}$ & Journal & $\mathrm{TC}$ & Title & Author/s & Year & $\mathrm{C} / \mathrm{Y}$ \\
\hline 41 & JOM & 203 & Balancing priorities: Decision-making in sustainable supply chain management & Wu, Z; Pagell, M & 2011 & 29 \\
\hline 42 & SCMIJ & $\begin{array}{c}20 \\
1\end{array}$ & Use the supply relationship to develop lean and green suppliers & Simpson, DE; Power, DF & 2005 & 15.46 \\
\hline 43 & $\mathrm{JCP}$ & 200 & $\begin{array}{l}\text { Integration of artificial neural network and MADA methods for green supplier } \\
\text { selection }\end{array}$ & Kuo, RJ; Wang, YC; Tien, FC & 2010 & 25.00 \\
\hline 44 & ESA & 199 & $\begin{array}{l}\text { Supplier selection using fuzzy AHP and fuzzy multi-objective linear } \\
\text { programming for developing low carbon supply chain }\end{array}$ & $\begin{array}{l}\text { Shaw, K; Shankar, R; Yadav, SS; } \\
\text { Thakur, LS }\end{array}$ & 2012 & 33.17 \\
\hline 45 & SCMIJ & 199 & Green supply chain management practices: impact on performance & $\begin{array}{l}\text { Green, KW Jr.; Zelbst, PJ; Meacham, } \\
\text { J; et al. }\end{array}$ & 2012 & 33.17 \\
\hline 46 & SCMIJ & 198 & $\begin{array}{l}\text { Drivers for the participation of small and medium-sized suppliers in green } \\
\text { supply chain initiatives }\end{array}$ & Lee, SY & 2008 & 19.80 \\
\hline 47 & OIJMS & 193 & $\begin{array}{l}\text { Firm-level correlates of emergent green supply chain management practices in } \\
\text { the Chinese context }\end{array}$ & $\begin{array}{l}\text { Zhu, QH; Sarkis, J; Cordeiro, JJ; Lai, } \\
\text { KH }\end{array}$ & 2008 & 19.30 \\
\hline 48 & SCMIJ & 191 & $\begin{array}{l}\text { Making connections: a review of supply chain management sustainability } \\
\text { literature }\end{array}$ & Ashby, A; Leat, M; Hudson-Smith, M & 2012 & 31.83 \\
\hline 49 & JSCM & 190 & $\begin{array}{l}\text { Corporate social responsibility reports: A thematic analysis related to supply } \\
\text { chain management }\end{array}$ & Tate, WL; Ellram, LM; Kirchoff, JF & 2010 & 23.75 \\
\hline 50 & POM & 188 & $\begin{array}{l}\text { Drivers and Enablers That Foster Environmental Management Capabilities in } \\
\text { Small- and Medium-Sized Suppliers in Supply Chains }\end{array}$ & Lee, SY; Klassen, RD & 2008 & 18.80 \\
\hline
\end{tabular}

Abbreviations available in Table 1 except for: $\mathrm{R}=\mathrm{Rank}$; $\mathrm{C} / \mathrm{Y}=$ Citations per year; $\mathrm{JCP}=$ Journal of Cleaner Production; IJMR $=$ International Journal of

Management Reviews; JOM = Journal of Operations Management; IJPLDL = International Journal of Physical Distribution \& Logistics Management; IJOPM = International Journal of Operations \& Production Management; IJPE = International Journal of Production Economics; JSCM = Journal of Supply Chain

Management; IJPR = International Journal of Production Research; EJOR = European Journal of Operational Research; MQ = MIS Quarterly; TRE =

Transportation Research Part E-Logistics and Transportation Review; ESA = Expert Systems with Applications; POM = Production and Operations

Management; RCR = Resource Conversation and Recycling; OIJMS = Omega-International Journal of Management Science; DSS = Decision Support Systems; SCMIJ = Supply Chain Management-an International Journal; M\&SOM = Manufacturing \& Service Operations Management; JSCM = Journal of Supply Chain

Management; JEM = Journal of Environmental Management. 
Table 3

Most cited documents in GSC publications

\begin{tabular}{|c|c|c|c|}
\hline $\mathrm{R}$ & cited reference & citations & TLS \\
\hline 1 & Srivastava SK, 2007, Int J Manag Rev, v9, p53 & 388 & 381 \\
\hline 2 & Zhu QH, 2004, J Oper Manag, v22, p265 & 374 & 374 \\
\hline 3 & Seuring S, 2008, J Clean Prod, v16, p1699 & 348 & 346 \\
\hline 4 & Rao P, 2005, Int J Oper Prod Man, v25, p898 & 323 & 323 \\
\hline 5 & Vachon S, 2006, Int J Oper Prod man, v26, p795 & 242 & 241 \\
\hline 6 & Sarkis J, 2011, Int J Prod Econ, v130, p1 & 223 & 223 \\
\hline 7 & Sarkis J, 2003, J Clean Prod, v11, p397 & 220 & 219 \\
\hline 8 & Carter CR, 2008, Int J Phys Distr Log, v38 & 214 & 213 \\
\hline 9 & Vachon S, 2008, Int J Prod Econ, v111, p299 & 204 & 203 \\
\hline 10 & Zhu QH, 2005, Int J Oper Prod Man, v25, p449 & 203 & 203 \\
\hline 11 & Porter ME, 1995, Harvard Bus Rev, v73, p120 & 202 & 201 \\
\hline 12 & Hart S1, 1995, Acad Manage Rev, v20, p986 & 200 & 200 \\
\hline 13 & Zhu QH, 2008, Int J Prod Econ, v111, p261 & 191 & 191 \\
\hline 14 & Bowen FE, 2001, Prod Oper Manag, v10, p174 & 187 & 187 \\
\hline 15 & Hervani AA, 2005, Benchmarking, v12, p330 & 170 & 170 \\
\hline 16 & LInton JD, 2007, J Oper Manag, v25, p1075 & 170 & 169 \\
\hline 17 & Kleindorfer PR, 2005, Prod Oper Manag, v14, p482 & 165 & 163 \\
\hline 18 & Zhu QH, 2006, J Clean Prod, v14, p472 & 158 & 158 \\
\hline 19 & Zhu QH, 2007, J Clean Prod, v15, p1041 & 156 & 156 \\
\hline 20 & Rao P, 2002, Int J Oper Prod Man, v22 & 154 & 154 \\
\hline 21 & Walker H, 2008, Journal Purchas Supply Manag, v14, p69 & 150 & 150 \\
\hline 22 & Min H, 2001, Int J Oper Prod Man, v21, p1222 & 139 & 138 \\
\hline 23 & Zhu QH, 2007, Int J Prod Res, v45, p4333 & 138 & 137 \\
\hline 24 & Klassen RD, 1996, Manage Sci, v42, p1199 & 125 & 125 \\
\hline 25 & Russo MV, 1997, Acad Manage J, v40, p534 & 123 & 123 \\
\hline 26 & Handfield R, 2002, Eur J Oper Res, v141, p70 & 121 & 120 \\
\hline 27 & Geffen CA, 2000, Int J Oper Prod Man, v20 & 120 & 120 \\
\hline 28 & King AA, 2001, Prod Oper Manag, v10, p244 & 120 & 120 \\
\hline 29 & Fornell C, 1981, J Marketing Res, v18, p39 & 117 & 116 \\
\hline 30 & ArmStrong JS, 1977, J Marketing Res, v14, p396 & 111 & 111 \\
\hline
\end{tabular}

Abbreviations: TLS - Total Link Strength 


\section{Table}

4

Citing article of GSC: Journals

\begin{tabular}{|c|c|c|c|c|c|c|}
\hline $\mathrm{R}$ & Journal & $95-02$ & 03-07 & $08-12$ & $13-17$ & $\mathrm{TP}$ \\
\hline 1 & J. of Cleaner Production & 2 & 8 & 24 & 243 & 277 \\
\hline 2 & Int J. of Production Economics & - & 3 & 38 & 91 & 132 \\
\hline 3 & Sustainability & - & - & - & 74 & 74 \\
\hline 4 & Int J. of Production Research & - & 6 & 20 & 46 & 72 \\
\hline 5 & Supply Chain Management an Int J. & - & 2 & 15 & 29 & 46 \\
\hline 6 & Business Strategy and the environment & - & - & 14 & 23 & 37 \\
\hline 7 & $\begin{array}{l}\text { Transportation Research Part E Logistics } \\
\text { and Transportation Review }\end{array}$ & 1 & 1 & 10 & 23 & 35 \\
\hline 8 & Production Planning Control & - & - & 6 & 25 & 31 \\
\hline 9 & Resources conservation and Recycling & - & - & 10 & 21 & 31 \\
\hline 10 & $\begin{array}{l}\text { Int J. of Physical Distribution Logistics } \\
\text { Management }\end{array}$ & - & - & 12 & 18 & 30 \\
\hline 11 & Computers \& Industrial Engineering & - & - & 3 & 26 & 29 \\
\hline 12 & Int J. of Operations Production Management & 1 & 5 & 4 & 18 & 28 \\
\hline 13 & European J. of Operational Research & 1 & 1 & 2 & 21 & 25 \\
\hline 14 & Industrial Management \& Data Systems & 1 & - & 4 & 15 & 20 \\
\hline 15 & Industrial Marketing Management & - & - & 8 & 12 & 20 \\
\hline 16 & Expert Systems with Applications & - & - & 9 & 9 & 18 \\
\hline 17 & Benchmarking an Int $\mathrm{J}$. & - & - & - & 17 & 17 \\
\hline 18 & Int J. of Logistics Management & - & - & 4 & 12 & 16 \\
\hline 19 & J. of Purchasing and Supply Management & - & - & 6 & 9 & 15 \\
\hline 20 & $\begin{array}{l}\text { Int J. of Advanced Manufacturing } \\
\text { Technology }\end{array}$ & - & - & 2 & 11 & 13 \\
\hline 21 & OMEGA Int J. of Management Science & - & - & 3 & 10 & 13 \\
\hline 22 & J. of Environmental Management & - & 2 & 4 & 6 & 12 \\
\hline 23 & Renewable Sustainable Energy Reviews & - & - & - & 12 & 12 \\
\hline 24 & Int J. of Logistics Research and Applications & - & - & 4 & 7 & 11 \\
\hline 25 & J. of Supply Chain Management & - & - & 3 & 8 & 11 \\
\hline 26 & $\begin{array}{l}\text { Transportation Research Part D Transport } \\
\text { and Environment }\end{array}$ & - & - & 1 & 10 & 11 \\
\hline 27 & $\begin{array}{l}\text { Int J. of Environmental Science and } \\
\text { Technology }\end{array}$ & - & 1 & 4 & 5 & 10 \\
\hline 28 & $\begin{array}{l}\text { J. of Manufacturing Technology } \\
\text { Management }\end{array}$ & - & - & - & 10 & 10 \\
\hline 29 & Mathematical Problems in Engineering & - & - & - & 10 & 10 \\
\hline 30 & Annals of Operations Research & - & - & - & 9 & 9 \\
\hline
\end{tabular}

Abbreviations available in Table $\underline{1}$ and $\underline{2}$ except: 95-96, 97-01, 02-06, 07-11, 12-16 - Number of papers published in GSC in the five-year period considered. 
Table 5

Citing articles of GSC: Authors, universities and countries

\begin{tabular}{|c|c|c|c|c|c|c|}
\hline $\mathrm{R}$ & Author & $\mathrm{TP}$ & Institution & $\mathrm{TP}$ & Country & $\mathrm{TP}$ \\
\hline 1 & Sarkis J & 3512 & Clarck U. & 3049 & Peoples R China+Taiwan & 3135 \\
\hline 2 & Zhu QH & 2335 & Hong Kong Polytechnic U. & 2528 & Peoples R China & 2371 \\
\hline 3 & Seuring S & 1862 & Dalian U. Technology & 2478 & USA & 2128 \\
\hline 4 & Lai KH & 1706 & U. Kassel & 1879 & UK & 1186 \\
\hline 5 & Govindan $\mathrm{K}$ & 1468 & Western U. Western Ontario & 1791 & Taiwan & 764 \\
\hline 6 & Klassen RD & 1421 & U. Southern Denmark & 1514 & Germany & 695 \\
\hline 7 & Vachon S & 1306 & U. Montreal & 895 & India & 684 \\
\hline 8 & Carter CR & 1183 & Worchester Polytechnic U. & 803 & Spain & 659 \\
\hline 9 & Geng Y & 848 & Khalifa U. Science Technology & 736 & Italy & 653 \\
\hline 10 & Pagell M & 738 & Erasmus U. Rotterdam & 730 & Australia & 566 \\
\hline 11 & Diabat A & 736 & U. East Anglia & 685 & Canada & 557 \\
\hline 12 & $\mathrm{Wu} \mathrm{ZH}$ & 667 & National Cheng Kung U. & 608 & Malaysia & 482 \\
\hline 13 & Kannan D & 637 & Aalborg U. & 603 & France & 472 \\
\hline 14 & Searcy C & 536 & National Central U. & 595 & Iran & 470 \\
\hline 15 & Lee SY & 523 & Chinese Academy of Sciences & 569 & Netherlands & 457 \\
\hline 16 & Gunasekaran A & 511 & U. Tennessee Knoxville & 531 & Brazil & 428 \\
\hline 17 & Chan HK & 509 & U. Estadual Paulista & 525 & Turkey & 364 \\
\hline 18 & Jabbour CJC & 508 & National Taipei U. Technology & 522 & Denmark & 329 \\
\hline 19 & Tseng ML & 480 & Wageningen U. Research & 515 & Sweden & 323 \\
\hline 20 & Buyukozkan G & 468 & U. Nova de Lisboa & 499 & South Korea & 292 \\
\hline 21 & Sheu JB & 424 & National Taiwan U. & 499 & Finland & 195 \\
\hline 22 & Tate WL & 418 & National Taiwan U. Science and Technology & 486 & Japan & 183 \\
\hline 23 & Hsu CW & 407 & U. Teknologi Malaysia & 482 & Portugal & 169 \\
\hline 24 & Jabbour ABLD & 347 & Cardiff $U$. & 475 & Belgium & 160 \\
\hline 25 & Cruz-Machado V & 345 & Esade Business School & 458 & Greece & 158 \\
\hline 26 & Azevedo SG & 340 & Lunghwa U. Sci Technology & 442 & Switzerland & 156 \\
\hline 27 & Kuo TC & 332 & U. Bath & 438 & Norway & 150 \\
\hline 28 & Bai CG & 319 & Chung Yuan Christian U. & 429 & Singapore & 149 \\
\hline 29 & Koh SCL & 313 & National Tsing Hua U. & 400 & Poland & 132 \\
\hline 30 & Carvalho H & 312 & U. Nottingham & 386 & New Zealand & 114 \\
\hline
\end{tabular}

Abbreviations available in Tables 1 and 2 . 
Table 6

The most productive and influential institutions in GSC

\begin{tabular}{|c|c|c|c|c|c|c|c|c|c|c|c|c|}
\hline $\mathrm{R}$ & Institution & Country & $\mathrm{TP}$ & $\mathrm{TC}$ & $\mathrm{H}$ & $\mathrm{C} / \mathrm{P}$ & $\geq 50$ & $\geq 25$ & $\geq 5$ & ARWU & QS & Top 50 \\
\hline 1 & Hong Kong Polytechnic U. & Peoples R China & 60 & 4086 & 29 & 68.10 & 21 & 32 & 55 & $201-300$ & 111 & 7 \\
\hline 2 & U. Southern Denmark & Denmark & 53 & 2517 & 28 & 47.49 & 15 & 30 & 46 & $301-400$ & 390 & 2 \\
\hline 3 & Dalian U. Technology & Peoples R China & 37 & 5026 & 26 & 135.84 & 21 & 26 & 36 & $301-400$ & $481-490$ & 10 \\
\hline 4 & Clarck U. & USA & 37 & 6172 & 31 & 166.81 & 29 & 34 & 37 & $601-700$ & $471-480$ & 12 \\
\hline 5 & Worcester Polytechnic Institute & USA & 29 & 1029 & 16 & 35.48 & 4 & 10 & 22 & $701-800$ & $601-650$ & 1 \\
\hline 6 & U. Estadual Paulista & Brazil & 26 & 678 & 13 & 26.08 & 3 & 8 & 21 & - & - & - \\
\hline 7 & Islamic Azad U. & Iran & 23 & 321 & 10 & 13.96 & 1 & 3 & 18 & - & - & - \\
\hline 8 & U. Teknologi Malaysia & Malaysia & 20 & 515 & 10 & 25.75 & 4 & 7 & 13 & $701-800$ & 288 & - \\
\hline 9 & Wageningen U. Research & Netherlands & 20 & 547 & 10 & 27.35 & 2 & 5 & 14 & - & 119 & 1 \\
\hline 10 & National Kaohsiung U. Science Technology & Peoples R China & 20 & 240 & 7 & 12.00 & 2 & 3 & 9 & $301-400$ & 85 & - \\
\hline 11 & U. Tehran & Iran & 19 & 413 & 10 & 21.74 & 3 & 7 & 12 & $301-400$ & $551-600$ & - \\
\hline 12 & Aalborg U. & Denmark & 19 & 796 & 10 & 41.89 & 6 & 7 & 13 & $201-300$ & 374 & - \\
\hline 13 & U. Nova de Lisboa & Portugal & 18 & 638 & 12 & 35.44 & 4 & 9 & 15 & $501-600$ & 366 & - \\
\hline 14 & U. Sheffield & UK & 18 & 413 & 11 & 22.94 & 3 & 6 & 15 & $101-150$ & 84 & - \\
\hline 15 & U. East Anglia & UK & 18 & 767 & 13 & 42.61 & 4 & 10 & 16 & $301-400$ & 252 & - \\
\hline 16 & U. Kassel & Germany & 17 & 2463 & 11 & 144.88 & 7 & 10 & 12 & - & - & 3 \\
\hline 17 & Cranfield U. & UK & 17 & 263 & 9 & 15.47 & - & 5 & 13 & - & - & - \\
\hline 18 & Lunghwa U. Science and Technology & People R China & 16 & 529 & 11 & 33.06 & 3 & 6 & 15 & - & - & - \\
\hline 19 & Chinese Academy of Sciences & Peoples R China & 16 & 697 & 11 & 43.56 & 7 & 9 & 12 & - & - & - \\
\hline 20 & National Taiwan U. & People R China & 16 & 540 & 8 & 33.75 & 4 & 4 & 10 & - & - & 1 \\
\hline 21 & Dongebi U. Finance Economics & Peoples R China & 16 & 298 & 8 & 18.63 & 2 & 5 & 11 & - & - & - \\
\hline 22 & Indian Institute of Technology Kharagpur & India & 15 & 244 & 8 & 16.27 & 2 & 4 & 9 & - & 185 & 1 \\
\hline 23 & Khalifa U. Science Tehnology & United Arab Emirates & 15 & 1014 & 14 & 67.60 & 6 & 12 & 15 & - & $401-410$ & 1 \\
\hline 24 & U. Nottingham & UK & 15 & 421 & 11 & 28.07 & 2 & 7 & 11 & $101-150$ & 75 & - \\
\hline 25 & Western U. Western Ontario & Canada & 15 & 2724 & 14 & 181.60 & 11 & 13 & 14 & - & 198 & 7 \\
\hline
\end{tabular}


Table 6 (continued)

\begin{tabular}{|c|c|c|c|c|c|c|c|c|c|c|c|c|}
\hline $\mathrm{R}$ & Institution & Country & $\mathrm{TP}$ & $\mathrm{TC}$ & $\mathrm{H}$ & $\mathrm{C} / \mathrm{P}$ & $\geq 50$ & $\geq 25$ & $\geq 5$ & ARWU & QS & Top 50 \\
\hline 26 & National Tsing Hua U. & Peoples R China & 15 & 428 & 9 & 28.53 & 2 & 4 & 11 & 48 & 151 & - \\
\hline 27 & U. Padua & Italy & 14 & 288 & 9 & 20.57 & 1 & 6 & 11 & $151-200$ & - & - \\
\hline 28 & U. Montreal & Canada & 14 & 1062 & 9 & 75.86 & 5 & 6 & 11 & $151-200$ & 126 & 2 \\
\hline 29 & Esade Business School & Spain & 14 & 530 & 9 & 37.86 & 3 & 8 & 12 & - & - & - \\
\hline 30 & U. Bath & UK & 14 & 519 & 13 & 37.07 & 3 & 10 & 14 & $501-600$ & 159 & - \\
\hline 31 & Polytechnic U. Milan & Italy & 14 & 306 & 8 & 21.86 & 2 & 5 & 11 & $201-300$ & 183 & - \\
\hline 32 & CNRS & France & 13 & 158 & 7 & 12.15 & 1 & 4 & 11 & - & - & - \\
\hline 33 & U. Tennessee Knoxville & USA & 13 & 580 & 10 & 44.62 & 2 & 5 & 12 & $201-300$ & $461-470$ & 2 \\
\hline 34 & Chung Yuan Christian U. & Peoples R China & 13 & 477 & 8 & 36.69 & 4 & 5 & 11 & $201-300$ & - & - \\
\hline 35 & U. Electronic Science Technology of China & Peoples R China & 12 & 129 & 8 & 10.75 & - & 1 & 8 & $201-300$ & - & - \\
\hline 36 & U. Sao Paulo & Brazil & 12 & 307 & 8 & 25.58 & 2 & 4 & 9 & $151-200$ & 120 & - \\
\hline 37 & National Central U. & Peoples R China & 12 & 754 & 9 & 62.83 & 1 & 2 & 9 & - & $411-420$ & - \\
\hline 38 & Lund $\mathrm{U}$. & Sweden & 12 & 109 & 6 & 9.08 & - & 2 & 8 & $101-150$ & 73 & - \\
\hline 39 & Cardiff U. & UK & 12 & 521 & 9 & 43.42 & 4 & 6 & 9 & 99 & 140 & - \\
\hline 40 & U. Leeds & UK & 12 & 257 & 9 & 21.42 & 1 & 4 & 11 & $101-150$ & 93 & - \\
\hline 41 & U. Beira Interior & Portugal & 12 & 400 & 8 & 33.33 & 1 & 6 & 9 & - & - & - \\
\hline 42 & Erasmus U. Rotterdam & Netherlands & 12 & 769 & 9 & 64.08 & 4 & 7 & 9 & $101-150$ & 183 & 1 \\
\hline 43 & U. Malaya & Malaysia & 11 & 124 & 6 & 11.27 & - & 1 & 7 & $401-500$ & 133 & - \\
\hline 44 & Tianjin U. & Peoples R China & 11 & 121 & 5 & 11 & - & 2 & 6 & $301-400$ & $481-490$ & - \\
\hline 45 & National Taipei U. Technology & People R China & 11 & 674 & 8 & 61.27 & 4 & 5 & 9 & - & $551-600$ & 2 \\
\hline 46 & U. Sydney & Australia & 11 & 263 & 8 & 23.91 & 2 & 4 & 9 & 83 & 46 & - \\
\hline 47 & U. Sains Malaysia & Malaysia & 11 & 236 & 6 & 21.45 & 1 & 4 & 6 & - & 330 & - \\
\hline 48 & Ryerson U. & Canada & 11 & 452 & 7 & 41.09 & 4 & 7 & 11 & - & 701 & 2 \\
\hline 49 & National Taiwan U. Science and Technology & People R China & 11 & 532 & 8 & 48.36 & 3 & 5 & 11 & & 243 & 1 \\
\hline 50 & U. Massachusetts Dartmouth & USA & 11 & 363 & 10 & 33 & 2 & 7 & 11 & - & - & - \\
\hline
\end{tabular}

Abbreviations available in Tables 1 and 2 except: $\mathrm{H}-\mathrm{h}$-index; $\mathrm{C} / \mathrm{P}-$ Cites per year; $\geq 25$ - Number of documents with equal or more than 25 citations; ARWU and QS - Ranking in the general ARWU and QS U. rankings; Top 50 - Paper among the fifty most cited publishes in GSC. 
Table 7

Most productive institutions in GSC throughout time

\begin{tabular}{|c|c|c|c|c|c|c|c|c|c|}
\hline & $1995-2007$ & & & $2008-2012$ & & & $2013-2017$ & & \\
\hline $\mathrm{R}$ & Institution & $\mathrm{TP}$ & $\mathrm{TC}$ & Institution & $\mathrm{TP}$ & $\mathrm{TC}$ & Institution & $\mathrm{TP}$ & $\mathrm{TC}$ \\
\hline 1 & Clark U. & 9 & 3133 & Hong Kong Polytechnic U. & 26 & 2840 & U. Southern Denmark & 51 & 2237 \\
\hline 2 & Dalian U. Technology & 7 & 2454 & Clarck U. & 20 & 2598 & Hong Kong Polytechnic U. & 32 & 722 \\
\hline 3 & Western U. Western Ontario & 6 & 1686 & Dalian U. Technology & 15 & 2108 & Worcester Polytechnic Institute & 29 & 1029 \\
\hline 4 & Clarckson U. & 3 & 850 & Chung Yuan Christian U. & 9 & 327 & Islamic Azad U. & 23 & 321 \\
\hline 5 & Aristotle U. Thessaloniki & 2 & 245 & National Chiao Tung U. & 8 & 538 & U. Estadual Paulista & 23 & 545 \\
\hline 6 & Asian Inst Management & 2 & 955 & National Tsing Hua U. & 8 & 388 & Aalborg U. & 19 & 796 \\
\hline 7 & Erasmus U. Rotterdam & 2 & 287 & $\begin{array}{l}\text { National Kaoshiung U. Science } \\
\text { Technology }\end{array}$ & 7 & 161 & U. Tehran & 18 & 336 \\
\hline 8 & U. Montreal & 2 & 271 & Erasmus U. Rotterdam & 6 & 432 & U. Teknologi Malaysia & 17 & 255 \\
\hline 9 & Hong Kong Polytechnic U. & 2 & 524 & Galatasaray U. & 6 & 556 & Dongbei U. Finance and Economics & 16 & 298 \\
\hline 10 & Kansas State U. & 2 & 44 & National Cheng Kung U. & 6 & 409 & Dalian U. Technology & 15 & 464 \\
\hline 12 & Norwegian U. Science and Technology & 2 & 82 & Wageningen U. Research & 6 & 344 & U. Sheffield & 15 & 261 \\
\hline 13 & U. California Los Angles & 2 & 208 & Western U. Western Ontario & 6 & 894 & Indian Institute of Technology Kharagpur & 14 & 187 \\
\hline 14 & U. Melbourne & 2 & 355 & Esade Business School & 5 & 349 & U. Nottingham & 14 & 392 \\
\hline 15 & York U. Canada & 2 & 46 & U. Montreal & 5 & 658 & Wageningen U. Research & 14 & 203 \\
\hline 16 & Austral U. & 1 & 3 & Monash U. & 5 & 227 & Chinese Academy of Science & 13 & 611 \\
\hline 17 & California State U. Northridge & 1 & 23 & National Taiwan U. & 5 & 199 & Cranfield U. & 13 & 178 \\
\hline 18 & Carnegie Mellon U. & 1 & 300 & Oregon State U. & 5 & 756 & Khalifa U. Science Technology & 13 & 684 \\
\hline 19 & Chalmers U. Technology & 1 & 257 & U. Nova de Lisboa & 5 & 368 & National Kaoshiung U. Science Tchnology & 13 & 79 \\
\hline 20 & Chung Hua U. & 1 & 19 & U. East Anglia & 5 & 498 & U. Nova de Lisboa & 13 & 270 \\
\hline
\end{tabular}


To gain a deeper insight into the results presented in Figure $\underline{1}$, Table $\underline{9}$ shows the fifty most cited journals. This report is divided into two classifications: global and periodic. The periodic analysis allowed us to study the effects and evolution of each of these journals.

Another noticeable item is the bibliographic coupling of institutions. Figure $\underline{2}$ presents a visual report of data involving at least one hundred papers and three hundred bibliographic coupling connections. In addition, this figure shows how each of the leading institutions is connected to the other institutions. To interpret this figure and justify the obtained result, two items are important: 1 . the proximity of the universities either in the same country or the same continent, 2 . the nationality of the authors. As it can be seen normally the collaboration occurs between the universities that are in the same area or even those that have the same language. In addition, in many cases the authors of the universities don't have the same nationality as the university and in some cases, it is observed that one author collaborates with a university form his nationality.

Figure $\underline{3}$ reports the type and level of co-authorship between authors who have published at least eighty papers. The lines between authors' labels show the co-authorship relationship. The more lines there are the higher the level of co-authorship. As it can be seen among the clusters of this figure there are 3 main clusters that their cores are the Sarkis, Govindan and Zhu that have the highest level of the co-authorship respectively.

Figure 4 presents bibliographic coupling of countries that publish in GSC with a threshold of fifty papers. The size of the labels reflects the country's number of publications. The USA is the most productive country and China and the UK(England, Scotland, Wales and North Ireland) are the second and third most productive countries. Also, the links among the countries demonstrate the 
level of collaboration that based on what said before about the institutions usually this collaboration happens among the countries with geographical proximity or language proximity.

The last item in this analysis is the most common keywords used by authors publishing in the field of GSC. To obtain the pertinent results, a co-occurrence of author keywords should be developed. Figure $\underline{5}$ presents a visual report of keywords that appear one hundred times or more, as well as the three hundred most frequent co-occurrences. The most common keywords are sustainability, green supply chain management, and supply chain management. Table $\underline{10}$ reports the results of Figure 5 . This table shows the forty most common keywords in the field of GSC both globally and periodically. This figure and this table disclose one interesting result that during the years of this study the interest to various keywords change. In the other words some keywords don't exist during the very first years of the analysis but in the next years gain importance and vice versa. In addition, the relationship among the keywords to somehow show the approach of the publications in this area.

\section{Conclusions}

This study presents a bibliometric overview of publications on GSC from 1995 until 2017. The study uses the WoS Core Collection database to analyze publications in the abovementioned period. The results show a significant growth of publications on GSC during the years surveyed in this paper. 
Table 8

\begin{tabular}{|c|c|c|c|c|c|c|c|c|c|c|c|c|c|}
\hline & Total & & & & & $1995-2002$ & & 2003-2007 & & $2008-2012$ & & 2013-2017 & \\
\hline $\mathrm{R}$ & Country & $\mathrm{TP}$ & $\mathrm{TC}$ & $\mathrm{H}$ & $\mathrm{C} / \mathrm{P}$ & $\mathrm{TP}$ & $\mathrm{TC}$ & $\mathrm{TP}$ & $\mathrm{TC}$ & $\mathrm{TP}$ & $\mathrm{TC}$ & $\mathrm{TP}$ & $\mathrm{TC}$ \\
\hline 1 & China (Peoples R China+Taiwan) & 467 & 14732 & 60 & 31.55 & - & - & 11 & 3020 & 100 & 6289 & 356 & 5423 \\
\hline 2 & USA & 381 & 20445 & 73 & 53.66 & 7 & 854 & 24 & 5739 & 99 & 8882 & 251 & 4970 \\
\hline 3 & Peoples R China & 323 & 10003 & 46 & 30.97 & - & - & 7 & 2454 & 45 & 3578 & 271 & 3971 \\
\hline 4 & UK & 257 & 6665 & 46 & 25.93 & 3 & 112 & 6 & 456 & 53 & 2889 & 195 & 3208 \\
\hline 5 & Taiwan & 161 & 5454 & 40 & 33.88 & - & - & 4 & 566 & 58 & 3102 & 99 & 1786 \\
\hline 6 & India & 141 & 4525 & 32 & 32.09 & - & - & 1 & 1079 & 10 & 737 & 130 & 2709 \\
\hline 7 & Italy & 100 & 1897 & 27 & 18.97 & - & - & 1 & 76 & 12 & 525 & 87 & 1296 \\
\hline 8 & Germany & 94 & 4134 & 29 & 43.98 & - & - & 2 & 162 & 17 & 2151 & 75 & 1821 \\
\hline 9 & Canada & 92 & 6005 & 35 & 65.27 & 1 & 21 & 10 & 2110 & 21 & 2378 & 60 & 1496 \\
\hline 10 & Denmark & 88 & 3415 & 31 & 38.81 & - & - & - & - & 6 & 527 & 82 & 2888 \\
\hline 11 & Iran & 80 & 1614 & 21 & 20.18 & - & - & - & - & 3 & 124 & 77 & 1490 \\
\hline 12 & Spain & 78 & 2050 & 25 & 26.28 & - & - & 2 & 157 & 22 & 1105 & 54 & 788 \\
\hline 13 & Brazil & 75 & 1172 & 19 & 15.63 & - & - & - & - & 6 & 236 & 69 & 936 \\
\hline 14 & France & 75 & 2063 & 23 & 27.51 & - & - & 1 & 569 & 7 & 481 & 64 & 978 \\
\hline 15 & Australia & 72 & 2323 & 23 & 32.26 & 1 & 24 & 2 & 355 & 18 & 1194 & 51 & 750 \\
\hline 16 & Netherlands & 69 & 1851 & 23 & 26.83 & 2 & 287 & 4 & 110 & 14 & 716 & 49 & 738 \\
\hline 17 & Malaysia & 66 & 1170 & 19 & 17.73 & - & - & - & - & 7 & 491 & 59 & 679 \\
\hline 18 & South Korea & 45 & 1068 & 16 & 23.73 & - & - & 1 & 64 & 10 & 701 & 34 & 303 \\
\hline 19 & Turkey & 42 & 1282 & 18 & 30.52 & - & - & - & - & 14 & 930 & 28 & 352 \\
\hline 20 & Sweden & 38 & 886 & 15 & 23.32 & 1 & 257 & 1 & 11 & 10 & 364 & 26 & 254 \\
\hline 21 & U Arab Emirates & 35 & 2023 & 17 & 57.80 & - & - & 1 & 670 & 4 & 550 & 30 & 803 \\
\hline 22 & Portugal & 28 & 729 & 14 & 26.04 & - & - & - & - & 5 & 368 & 23 & 361 \\
\hline 23 & Japan & 26 & 479 & 9 & 18.42 & - & - & 2 & 173 & 4 & 156 & 20 & 150 \\
\hline 24 & Singapore & 21 & 676 & 12 & 32.19 & - & - & 1 & 6 & 6 & 419 & 14 & 251 \\
\hline 25 & South Africa & 21 & 205 & 6 & 9.762 & - & - & 1 & 50 & 2 & 91 & 18 & 64 \\
\hline 26 & Belgium & 20 & 331 & 10 & 16.55 & - & - & 1 & 71 & 1 & 66 & 18 & 194 \\
\hline 27 & Finland & 20 & 306 & 10 & 15.30 & - & - & - & - & 2 & 91 & 18 & 215 \\
\hline 28 & Greece & 20 & 997 & 12 & 49.85 & - & - & 2 & 245 & 7 & 558 & 11 & 194 \\
\hline 29 & Ireland & 20 & 627 & 13 & 31.35 & - & - & - & - & 4 & 156 & 16 & 462 \\
\hline 30 & Switzerland & 18 & 587 & 11 & 32.61 & - & - & - & - & 4 & 324 & 14 & 263 \\
\hline 31 & Poland & 17 & 240 & 8 & 14.12 & - & - & 1 & 50 & 2 & 66 & 14 & 124 \\
\hline 32 & Austria & 16 & 160 & 8 & 10 & - & - & - & - & - & - & 16 & 160 \\
\hline 33 & New Zealand & 16 & 246 & 7 & 15.38 & - & - & - & - & 5 & 183 & 11 & 63 \\
\hline 34 & Thailand & 15 & 121 & 5 & 8.067 & - & - & - & - & 2 & 22 & 13 & 99 \\
\hline 35 & Lithuania & 14 & 215 & 8 & 15.36 & - & - & - & - & 1 & 6 & 13 & 209 \\
\hline 36 & Norway & 12 & 368 & 8 & 30.67 & - & - & 3 & 150 & 2 & 79 & 7 & 139 \\
\hline 37 & Indonesia & 11 & 150 & 7 & 13.64 & - & - & - & - & 1 & 21 & 10 & 129 \\
\hline 38 & Philippines & 9 & 1314 & 8 & 146 & 1 & 285 & 1 & 670 & - & - & 7 & 359 \\
\hline 39 & Chile & 8 & 149 & 5 & 18.63 & - & - & 1 & 90 & - & - & 7 & 59 \\
\hline 40 & Colombia & 8 & 107 & 6 & 13.38 & - & - & - & - & - & - & 8 & 107 \\
\hline 41 & Mexico & 8 & 42 & 4 & 5.25 & - & - & - & - & - & - & 8 & 42 \\
\hline
\end{tabular}

Abbreviations available in previous tables. 


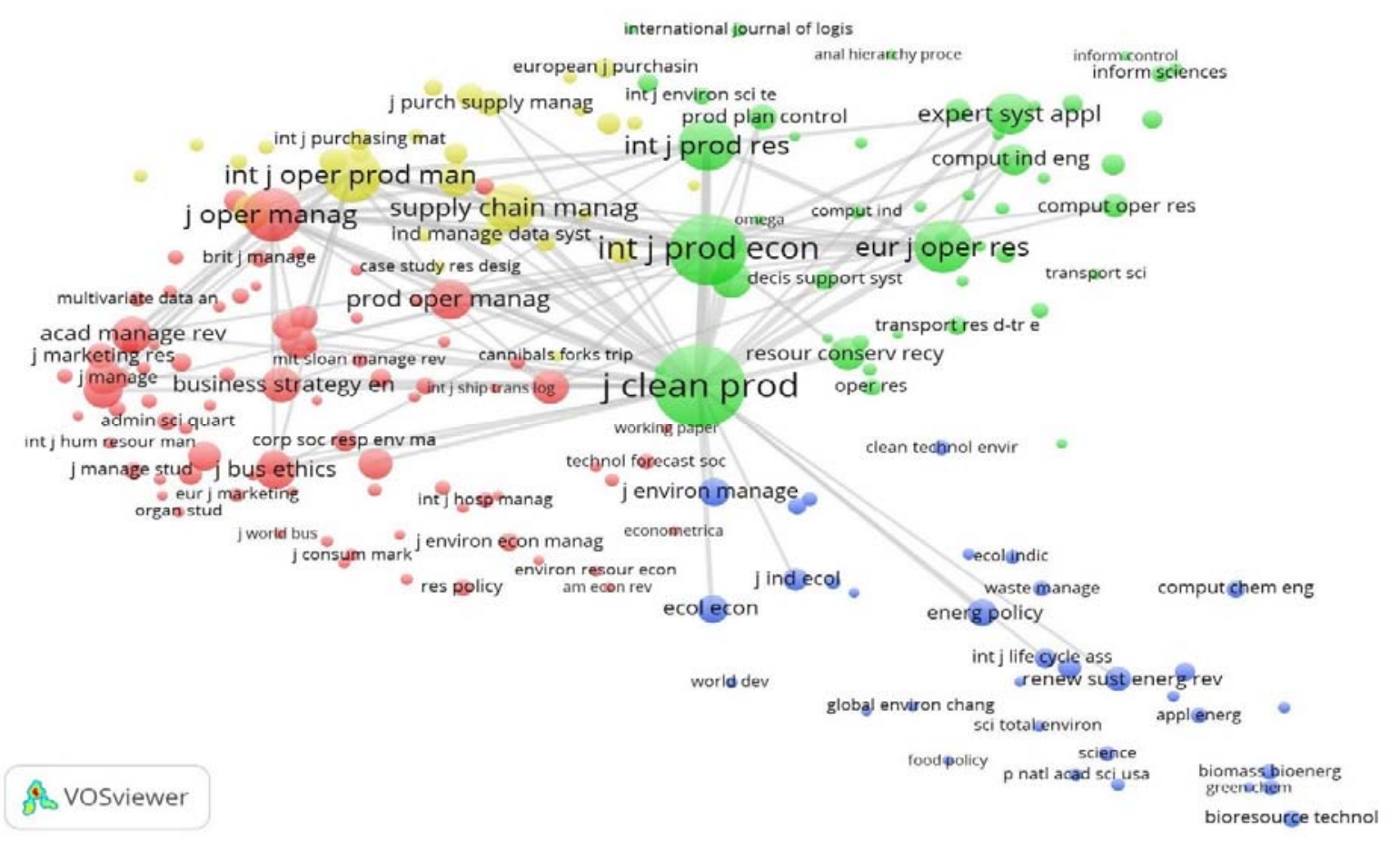

Fig. 1. Co-citation of journals cited in GSC

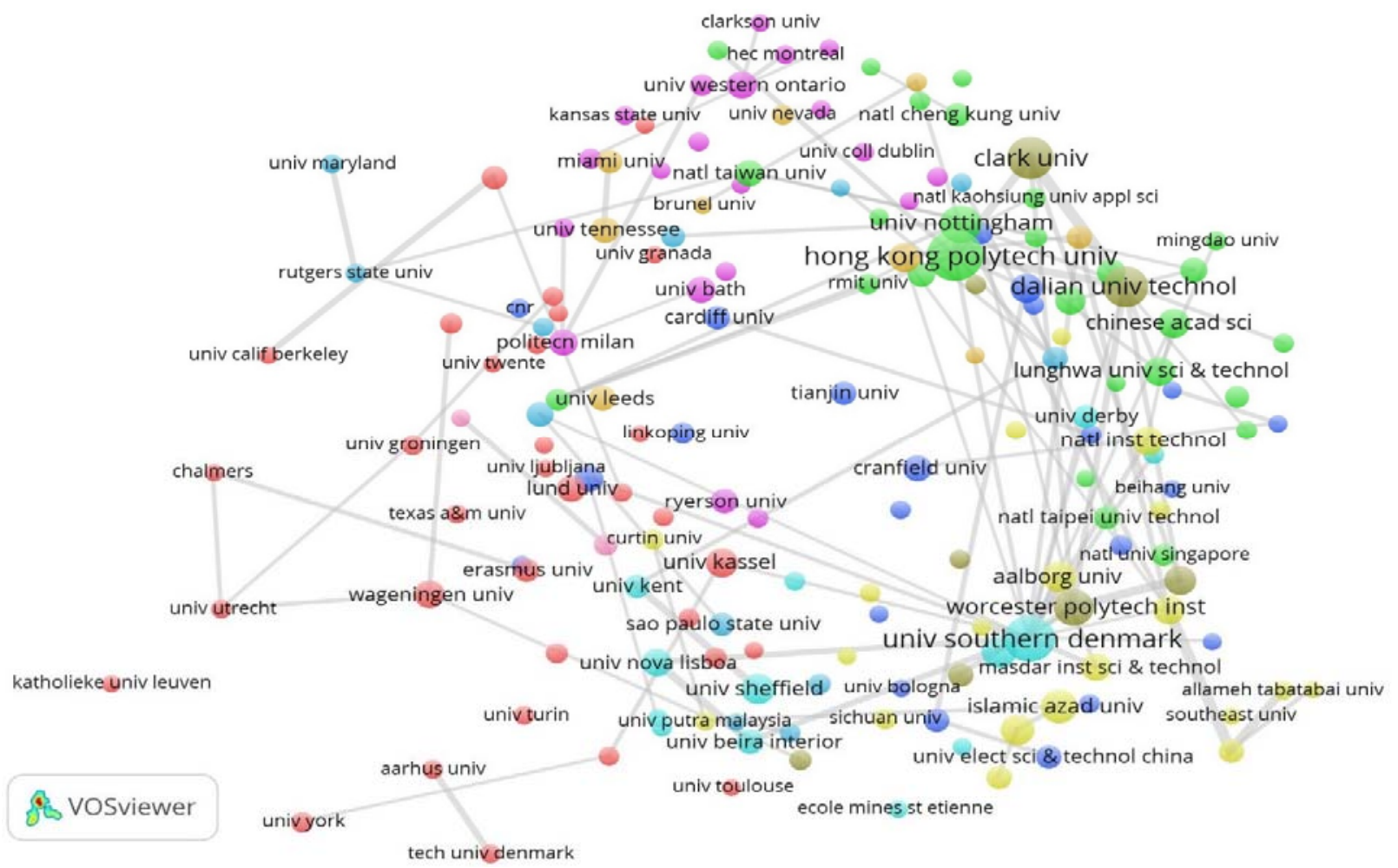

Fig. 2. Bibliographic coupling of institutions that publish in GSC 


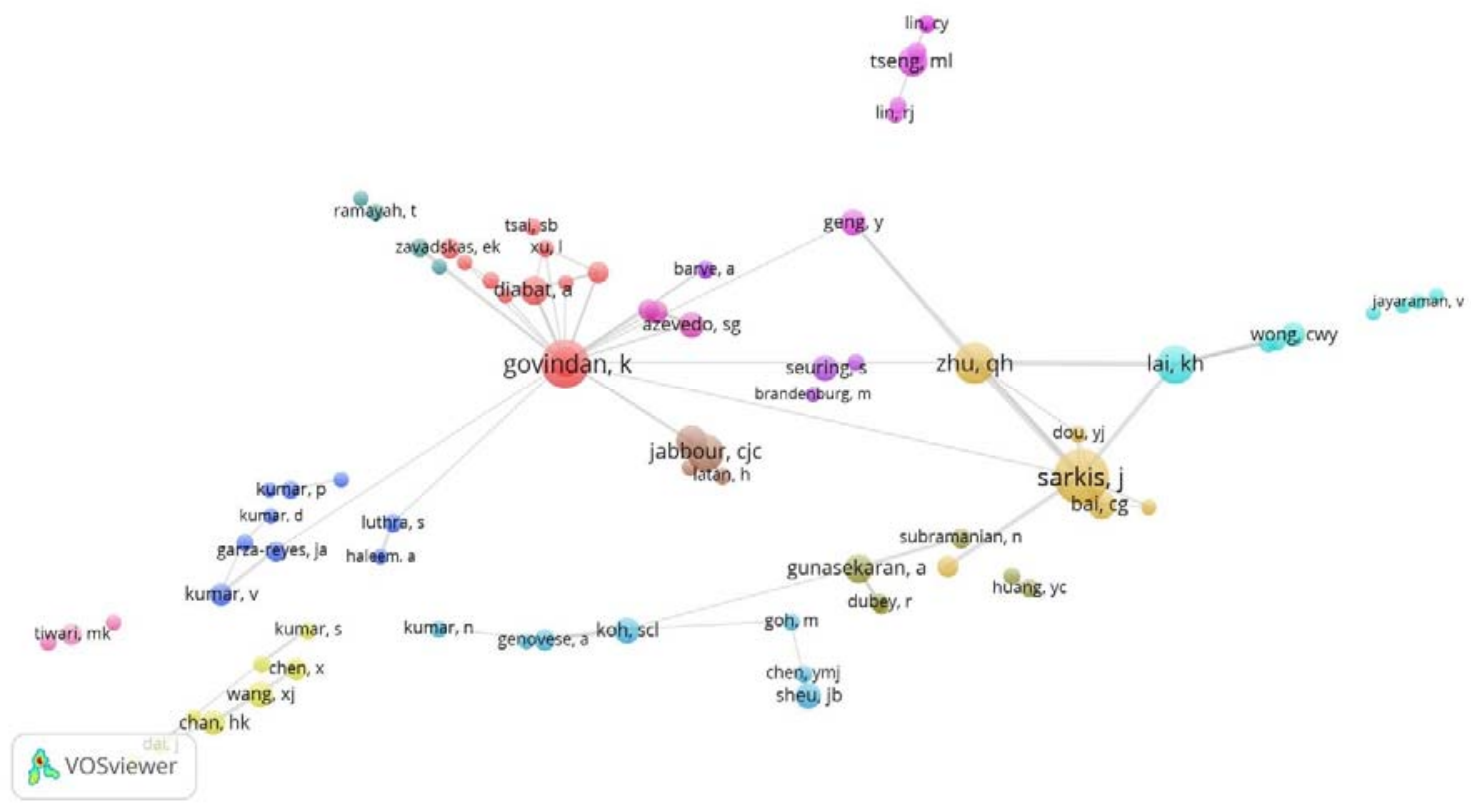

Fig. 3. Co-authorship of authors in GSC

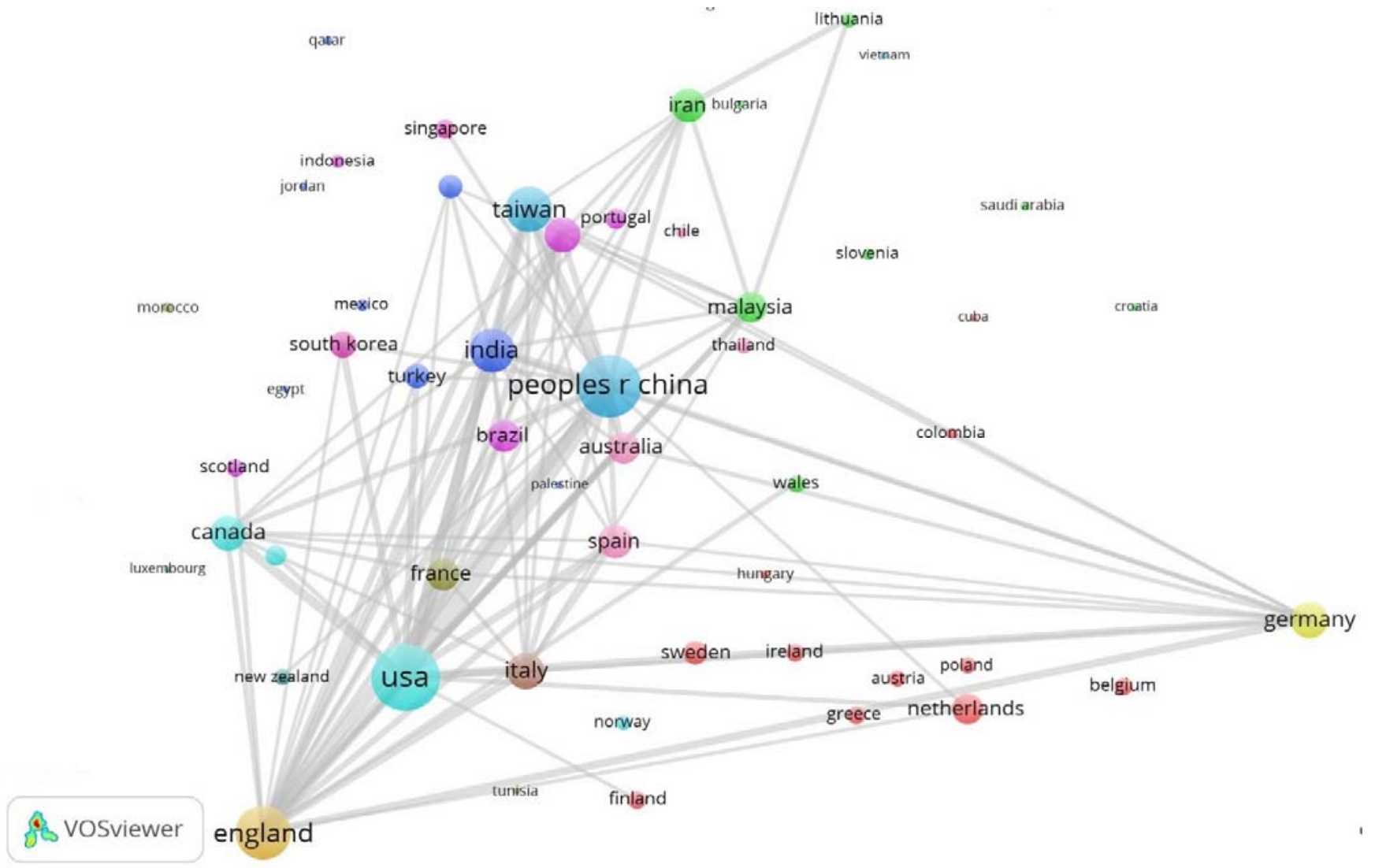

Fig. 4. Bibliographic coupling of countries that publish in GSC 
Table 9

Most cited journals in GSC

\begin{tabular}{|c|c|c|c|c|c|c|c|c|c|}
\hline \multirow[b]{2}{*}{$\mathrm{R}$} & \multirow[b]{2}{*}{ Journal } & \multicolumn{2}{|c|}{ Global } & \multicolumn{2}{|c|}{$1995-2007$} & \multicolumn{2}{|c|}{$2008-2012$} & \multicolumn{2}{|c|}{$2013-2017$} \\
\hline & & Cit & CLS & Cit & CLS & Cit & CLS & Cit & CLS \\
\hline 1 & J Clean Prod & 7404 & 6060.33 & 50 & 44.06 & 792 & 696.01 & 6562 & 5317.81 \\
\hline 2 & Int J Prod Econ & 5101 & 4511.32 & 25 & 22.93 & 590 & 526.98 & 4486 & 3959.63 \\
\hline 3 & Int J Oper Prod Man & 2851 & 2641.03 & 81 & 75.12 & 629 & 581.71 & 2141 & 1983.8 \\
\hline 4 & J Oper Manag & 2757 & 2552.53 & 75 & 69.24 & 619 & 568.44 & 2063 & 1913.74 \\
\hline 5 & Eur J Oper Res & 2670 & 2394.66 & 66 & 57 & 335 & 301.26 & 2269 & 2037.31 \\
\hline 6 & Int J Prod Res & 2635 & 2403.18 & 23 & 21.97 & 359 & 336.87 & 2253 & 2044.1 \\
\hline 7 & Supply Chain Manag & 2116 & 1996.12 & 22 & 21.39 & 206 & 196.3 & 871 & 828.76 \\
\hline 8 & Expert Syst Appl & 1476 & 1317.44 & - & - & 113 & 95.67 & 1363 & 1223.85 \\
\hline 9 & Prod Oper Manag & 1463 & 1369.9 & 97 & 77.53 & 384 & 361.39 & 982 & 931.82 \\
\hline 10 & J Bus Ethics & 1223 & 1136.93 & - & - & 179 & 168.03 & 1043 & 967.3 \\
\hline 11 & Transport Res E-log & 1177 & 1125.83 & 14 & 13.88 & 185 & 178.48 & 978 & 933.78 \\
\hline 12 & Acad Manage Rev & 1152 & 1105.6 & 35 & 33.96 & 329 & 313.39 & 788 & 757.99 \\
\hline 13 & Business Strategy En & 1108 & 1040.57 & 60 & 43.28 & 316 & 294.9 & 732 & 702.35 \\
\hline 14 & Acad Manage J & 1107 & 1051.94 & 54 & 50.24 & 299 & 282.03 & 754 & 719.32 \\
\hline 15 & J Supply Chain Manag & 1083 & 1031.46 & 6 & 5.96 & 206 & 196.3 & 871 & 828.76 \\
\hline 16 & Strategic Manage J & 1035 & 983.18 & 35 & 32.89 & 277 & 262.4 & 723 & 687.45 \\
\hline 17 & Manage Sci & 1023 & 954.94 & 42 & 38.33 & 255 & 235.65 & 726 & 680.16 \\
\hline 18 & Int J Phys Distr Log & 931 & 890.93 & - & - & 85 & 82.65 & 846 & 807.96 \\
\hline 19 & Harvard Bus Rev & 913 & 885.71 & 60 & 56.94 & 250 & 239.18 & 603 & 589.54 \\
\hline 20 & Resour Conserv Recy & 909 & 871.03 & 10 & 9.46 & 85 & 80.03 & 814 & 781.61 \\
\hline 21 & Omega-Int J Manage S & 876 & 850.49 & 12 & 11.8 & 171 & 164.43 & 693 & 674.15 \\
\hline 22 & Bus Strateg Environ & 804 & 765.62 & - & - & 93 & 88.43 & 709 & 674.67 \\
\hline 23 & Comput Ind Eng & 786 & 750.35 & 16 & 15.34 & 113 & 103.57 & 657 & 631.08 \\
\hline 24 & $\mathrm{~J}$ Marketing & 707 & 655.42 & 16 & 15.81 & 174 & 161.47 & 517 & 477.55 \\
\hline 25 & Ecol Econ & 682 & 646.76 & 4 & 3.93 & 89 & 82.95 & 589 & 558.03 \\
\hline 26 & Ind Market Manag & 677 & 641.46 & 7 & 6.96 & 127 & 117.46 & 543 & 516.54 \\
\hline 27 & J Environ Manage & 649 & 635.32 & 4 & 4 & 102 & 98.3 & 543 & 531.54 \\
\hline 28 & Energ Policy & 588 & 527.73 & - & - & 62 & 53.2 & 525 & 472.59 \\
\hline 29 & Calif Manage Rev & 544 & 533.64 & 49 & 46.71 & 170 & 166.41 & 325 & 320.9 \\
\hline 30 & J Bus Res & 521 & 506.42 & 6 & 5.87 & 93 & 90.55 & 422 & 409.9 \\
\hline 31 & J Purch Supply Manag & 516 & 500.87 & - & - & 19 & 18.86 & 497 & 481.91 \\
\hline 32 & J Business Logistics & 509 & 496.06 & 23 & 20.54 & 142 & 137.48 & 344 & 338.18 \\
\hline 33 & J Marketing Res & 503 & 491.52 & 10 & 9.8 & 119 & 116.09 & 374 & 365.5 \\
\hline 34 & Prod Plan Control & 500 & 476.89 & - & - & 32 & 31.17 & 468 & 445.75 \\
\hline 35 & Int J Manag Rev & 467 & 465.93 & - & - & 82 & 81.97 & 385 & 383.96 \\
\hline 36 & Comput Oper Res & 462 & 439.81 & - & - & 55 & 53.75 & 404 & 383.41 \\
\hline 37 & Renew Sust Energ Rev & 443 & 378.91 & - & - & 19 & 18.47 & 424 & 359.07 \\
\hline 38 & Int J Adv Manuf Tech & 426 & 410.52 & - & - & 20 & 19.95 & 406 & 390.72 \\
\hline 39 & Decision Sci & 420 & 413.54 & 30 & 29.22 & 99 & 98.05 & 291 & 286.31 \\
\hline 40 & Ind Manage Data Syst & 418 & 409.69 & - & - & 59 & 57.31 & 358 & 351.32 \\
\hline 41 & $\mathrm{~J}$ Ind Ecol & 385 & 365.24 & 24 & 23.48 & 95 & 92.93 & 266 & 250.67 \\
\hline 42 & Benchmarking & 378 & 370.67 & - & - & 56 & 55.7 & 322 & 314.95 \\
\hline 43 & Environ Sci Technol & 378 & 326.63 & 8 & 7.6 & 56 & 47.78 & 314 & 270.46 \\
\hline 44 & $\mathrm{~J}$ Manage & 376 & 370.89 & - & - & 67 & 66.08 & 307 & 302.74 \\
\hline 45 & Greener Management I & 370 & 357.53 & 36 & 34.12 & 171 & 162.55 & 163 & 161.19 \\
\hline 46 & Int J Logist Manag & 362 & 353.64 & 7 & 7 & 63 & 60.88 & 292 & 285.81 \\
\hline 47 & J Acad Market Sci & 355 & 340.24 & - & - & 60 & 57.76 & 293 & 280.34 \\
\hline 48 & Corp Soc Resp Env Ma & 351 & 344.26 & - & - & 38 & 37.76 & 313 & 306.42 \\
\hline 49 & Appl Math Model & 332 & 321.15 & - & - & 16 & 15.84 & 316 & 305.43 \\
\hline 50 & Int J Purchasing Mat & 330 & 323.13 & 36 & 33.99 & 113 & 109.96 & 181 & 179.21 \\
\hline
\end{tabular}


Table 10

Most common author keyword occurrences in GSC

\begin{tabular}{|c|c|c|c|c|c|c|c|c|c|}
\hline \multirow[b]{2}{*}{$\mathrm{R}$} & \multirow[b]{2}{*}{ Journal } & \multicolumn{2}{|c|}{ Global } & \multicolumn{2}{|c|}{ 1995-2007 } & \multicolumn{2}{|c|}{$2008-2012$} & \multicolumn{2}{|c|}{$2013-2017$} \\
\hline & & Oc & Co & Oc & Co & Oc & Co & Oc & Co \\
\hline 1 & Sustainability & 229 & 208 & 4 & 4 & 41 & 40 & 184 & 164 \\
\hline 2 & Green supply chain management & 176 & 150 & 5 & 5 & 36 & 27 & 135 & 118 \\
\hline 3 & Supply chain management & 165 & 146 & 15 & 15 & 52 & 46 & 98 & 85 \\
\hline 4 & Green supply chain & 128 & 88 & 3 & 3 & 30 & 18 & 95 & 67 \\
\hline 5 & Environmental management & 106 & 94 & 12 & 12 & 43 & 36 & 51 & 46 \\
\hline 6 & Supply chain & 96 & 83 & 8 & 8 & 16 & 13 & 72 & 62 \\
\hline 7 & Environmental performance & 62 & 55 & 3 & 3 & 14 & 12 & 45 & 40 \\
\hline 8 & Reverse logistics & 56 & 51 & 3 & 3 & 16 & 14 & 37 & 34 \\
\hline 9 & Sustainable development & 56 & 47 & 1 & 1 & 18 & 14 & 37 & 32 \\
\hline 10 & Environmental sustainability & 52 & 43 & 1 & 1 & 5 & 3 & 46 & 39 \\
\hline 11 & Sustainable supply chain management & 48 & 42 & - & - & 5 & 5 & 43 & 37 \\
\hline 12 & Environment & 40 & 37 & 1 & 1 & 12 & 11 & 27 & 25 \\
\hline 13 & Performance & 40 & 37 & 1 & 1 & 3 & 3 & 36 & 33 \\
\hline 14 & Life cycle assessment & 37 & 29 & 2 & 2 & 9 & 7 & 26 & 20 \\
\hline 15 & Literature review & 37 & 35 & - & - & 3 & 3 & 34 & 32 \\
\hline 16 & Supplier selection & 37 & 30 & - & - & 8 & 7 & 29 & 23 \\
\hline 17 & Sustainable supply chain & 37 & 36 & - & - & 3 & 2 & 34 & 34 \\
\hline 18 & China & 35 & 26 & 2 & 2 & 11 & 7 & 22 & 17 \\
\hline 19 & Green logistic & 34 & 29 & 0 & 0 & 11 & 8 & 23 & 21 \\
\hline 20 & Green & 30 & 28 & 1 & 1 & 3 & 3 & 26 & 24 \\
\hline 21 & Green supply chains & 30 & 25 & - & - & 3 & 2 & 27 & 23 \\
\hline 22 & Green supplier selection & 29 & 20 & - & - & 2 & - & 27 & 20 \\
\hline 23 & Green supply chain management ( $\mathrm{gscm}$ ) & 28 & 25 & - & - & 4 & 4 & 24 & 21 \\
\hline 24 & Case study & 27 & 23 & 1 & 1 & 2 & 1 & 24 & 21 \\
\hline 25 & Logistics & 26 & 24 & 1 & 1 & 5 & 5 & 20 & 18 \\
\hline 26 & Automotive industry & 25 & 24 & 1 & 1 & 5 & 5 & 19 & 18 \\
\hline 27 & Green innovation & 25 & 22 & - & - & 2 & 1 & 23 & 21 \\
\hline 28 & Carbon footprint & 24 & 21 & - & - & 10 & 8 & 14 & 13 \\
\hline 29 & Game theory & 24 & 22 & - & - & 3 & 3 & 21 & 19 \\
\hline 30 & Green marketing & 24 & 20 & 3 & 3 & 7 & 7 & 14 & 10 \\
\hline 31 & Corporate social responsibility & 23 & 22 & - & - & 8 & 8 & 15 & 14 \\
\hline 32 & Green manufacturing & 23 & 22 & 1 & 1 & 3 & 2 & 19 & 19 \\
\hline 33 & Institutional theory & 23 & 23 & 1 & 1 & 7 & 8 & 15 & 14 \\
\hline 34 & Sustainable operations & 23 & 18 & 1 & 1 & 3 & 1 & 19 & 16 \\
\hline 35 & Performance measurement & 22 & 21 & - & - & 4 & 4 & 18 & 17 \\
\hline 36 & Remanufacturing & 22 & 19 & - & - & 6 & 4 & 16 & 15 \\
\hline 37 & Closed-loop supply chain & 21 & 17 & - & - & 11 & 8 & 10 & 9 \\
\hline 38 & Firm performance & 21 & 15 & 1 & 1 & 3 & 2 & 17 & 12 \\
\hline 39 & Innovation & 21 & 19 & 1 & 1 & 3 & 2 & 17 & 16 \\
\hline 40 & Lean & 21 & 21 & - & - & 1 & 1 & 20 & 20 \\
\hline
\end{tabular}

Abbreviations: $\mathrm{R}=$ Rank; Oc = Author keyword occurrences; $\mathrm{Co}=$ Author keyword co-occurrences links. 


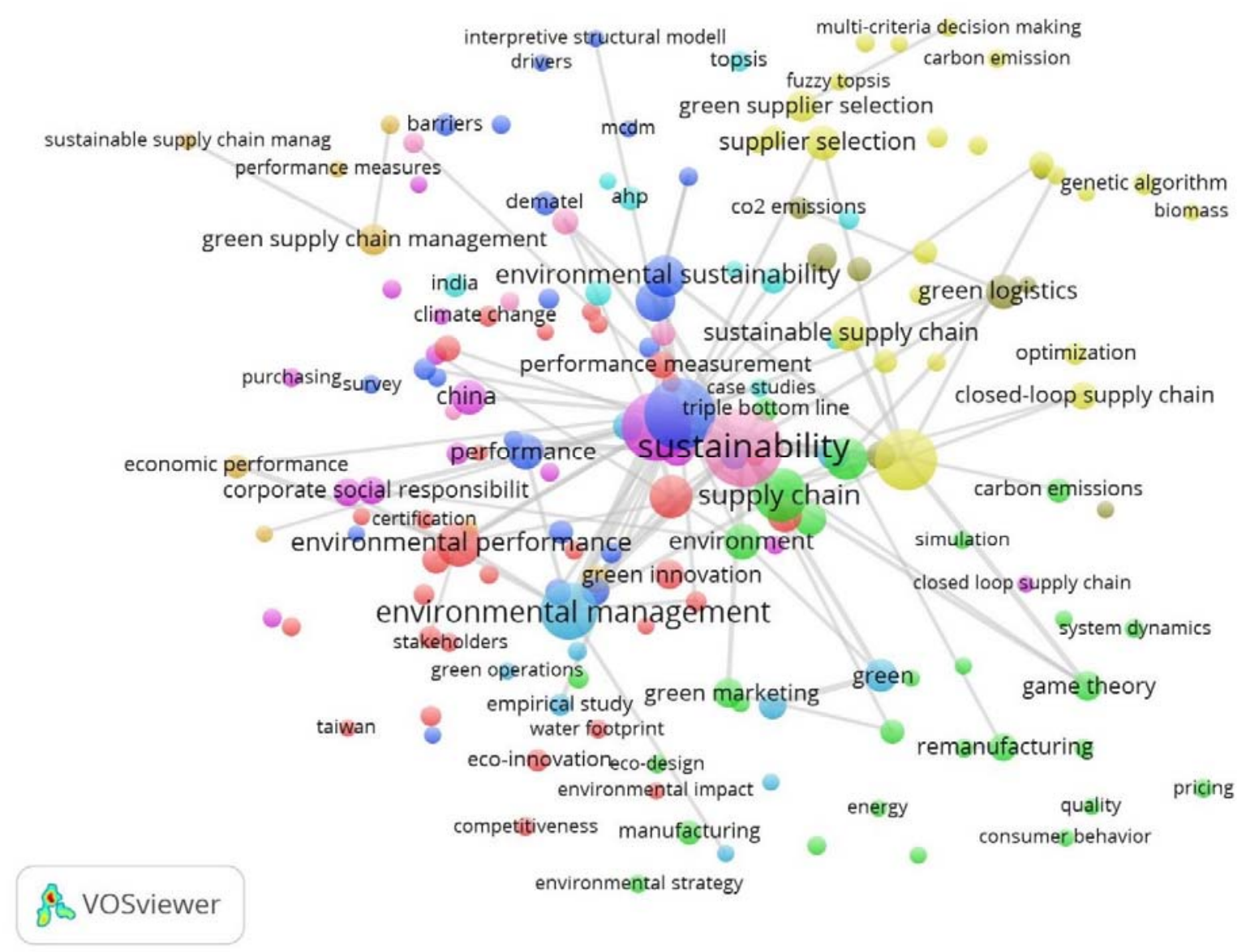

Fig. 5. Co-occurrence of author keywords of documents published in GSC

The work reports the leading institutions and countries of journals that have published papers on GSC. Although the USA is the most productive country, some Asian countries, especially China are quickly improving their rankings. The most productive and influential institution is the Hong Kong Polytechnic University. To justify the rapid growth of countries' number of publications in GSC there are many effective reasons such as: economic, environmental, social etc. (Lee et al. 2013). The companies found out that the key to improve the performance in various aspects is applying GSC practices and from the other point of view global and governmental obligations are the other items 
that can influence on this item. During the years of the study the developing countries including many Asian countries try to have a share in the studies around GSC from one side and from the other side their efforts are dedicated to improving the situation of some less-studied industries in terms of green supply chain issue.

By using the VOS viewer software, the study considers co-citations, bibliographic coupling, coauthorship and the co-occurrence of keywords. The graphic results confirm the table's outputs. The most important benefit of using a graphical representation is the ability to show the various connections among variables.

Note that this work provides a general overview of the publication and citation structure of GSC by using a wide range of indicators including the total number of papers and citations, $h$-index, cites per paper and several citation thresholds. Based on this methodology, we comprehensively reviewed published articles to uncover prominent works. The study includes all published papers from different countries by all authors working in the field, so the results are as accurate and complete as possible. In addition, by analyzing approximately 1900 papers, this study has reviewed more papers relative to previous works.

The paper is very useful for policy makers to understand the current trends in the field. Additionally, it is also very useful for $\mathrm{PhD}$ students and newcomers to get a quick overview of the current trends of the journal. Moreover, readers of the journal can complete their knowledge by reading these papers. Usually, experts in the field now well the field but it is very common that due to specialization, they do not know the whole field of the journal and therefore, by reading this paper they can complement and/or improve their knowledge very well. 
This work aims to present the data from different perspectives, so each reader can understand the data according to his or her interests and priorities. Nevertheless, many limitations exist due to the wide range of issues surveyed in this work, such as the use of Web of Science and the future evolution of the reported results over time. However, the expectations of the authors about the trend of the publications in this area following the trends during the past years is incremental. Additionally, it is important to say that after studying the trends it seems that Asian countries and specially China will experience a better ranking in the future in terms of the publications in this area.

\section{References}

Ahi P, Searcy C (2013) A comparative literature analysis of definitions for green and sustainable supply chain management. J Clean Prod 52:329-341

Albort-Morant G, Henseler J, Leal-Millán A, Cepeda-Carrión G (2017) Mapping the field: A bibliometric analysis of green innovation. Sustainability 9:1011

Alfalla-Luque R, Medina-Lopez C (2009) Supply chain management: Unheard of in the 1970s, core to today's company. Bus Hist 51:202-221

Alonso S, Cabrerizo FJ, Herrera-Viedma E, Herrera F (2009) h-Index: A review focused in its variants, computation and standardization for different scientific fields. J Informetr 3:273-289

Andrade A, Dominski FH, Coimbra DR (2017) Scientific production on indoor air quality of environments used for physical exercise and sports practice: Bibliometric analysis. J Environ Manage 196:188-200

Beske-Janssen P, Johnson MP, Schaltegger S (2015) 20 years of performance measurement in sustainable supply chain management-what has been achieved?' Supply Chain Manag 20:664-680

Broadus R (1987) Toward a definition of "bibliometrics". Scientometrics 12:373-379

Cancino C, Merigó JM, Coronado F, Dessouky Y, Dessouky M (2017) Forty years of Computers \& Industrial Engineering: A bibliometric analysis. Comput Ind Eng 113:614-629

Carter CR, Rogers DS (2008) A framework of sustainable supply chain management: moving toward new theory. Int J Phys Distr Log 38:60-387

Chang PL, Hsieh PN (2008) Bibliometric overview of operations research/management science research in Asia. Asia Pac J Oper Res 25:217-241

Charvet FF, Cooper MC, Gardner JT (2008) The Intellectual structure of the supply chain management: A bibliometric approach. J Bus Logist 29:47-43

Chen L, Zhao X, Tang O, Price L, Zhang S, Zhu W (2017) Supply chain collaboration for sustainability: A literature review and future research agenda. Int J Prod Econ 193:73-87

de Oliveira UR, Espindola LS, da Silva IR, da Silva IN, Rocha HM (2018) A systematic literature review on green supply chain management: research implications and future perspectives. J Clean Prod 187:537-561

Dragos CM, Dragos SL (2013) Bibliometric approach of factors affecting scientific productivity in environmental sciences and ecology. Sci Total Environ 449:184-188

Eltayeb TK, Zailani S, Ramayah T (2011) Green supply chain initiatives among certified companies in Malaysia and environmental sustainability: Investigating the outcomes. Resour Conserv Recy 55:495-506

Fahimnia B, Sarkis J, Davarzani H (2015) Green supply chain management: A review and bibliometric analysis. Int J Prod Econ 162:101-114

Feng Y, Zhu Q, Lai KH (2017) Corporate social responsibility for supply chain management: A literature review and bibliometric analysis. J Clean Prod 158:296-307

Fu HZ, Wang MH, Ho YS (2013) Mapping of drinking water research: A bibliometric analysis of research output during 1992-2011. Sci Total Environ 443:757-765

Govindan K, Rajendran S, Sarkis J, Murugesan P (2015) Multi criteria decision making approaches for green supplier 
evaluation and selection: a literature review. J Clean Prod 98:66-83

Hassini E, Surti C, Searcy C (2012) A literature review and a case study of sustainable supply chains with a focus on metrics. Int J Prod Econ 140:69-82

Hirsch JE (2005) An index to quantify an individual's scientific research output. Proceedings of the National Academy of Sciences of the United States of America 102:16569-16572

Hood W, Wilson C (2001) The literature of bibliometrics, scientometrics, and informetrics. Scientometrics 52:291-314

Hsieh PN, Chang PL (2009) An assessment of world-wide research productivity in production and operations management. Int J Prod Econ 120:540-551

Hu J, Ma Y, Zhang L, Gan F, Ho YS (2010) A historical review and bibliometric analysis of research on lead in drinking water field from 1991 to 2007. Sci Total Environ 408:1738-1744

Ioana-Toroimac G (2018) Outcomes of the hydromorphology integration in the Water Framework Directive: A review based on science mapping. J Environ Manage 206:1135-1144

Kainuma Y, Tawara N (2006) A multiple attribute utility theory approach to lean and green supply chain management. Int J Prod Econ 101:99-108

Kessler MM (1963) Bibliographic coupling between scientific papers. J Assoc Inf Sci Tech 14:10-25

Khan MA, Ho YS (2012) Top-cited articles in environmental sciences: Merits and demerits of citation analysis. Sci Total Environ 431:122-127

Kumar S, Teichman S, Timpernagel T (2012) A green supply chain is a requirement for profitability. Int J Prod Res 50:1278-1296

Laengle S, Merigó JM, Miranda J, Słowiński R, Bomze I, Borgonovo E, Dyson RG, Oliveira JF, Teunter R (2017) Forty years of the European Journal of Operational Research: A bibliometric overview. Eur J Oper Res 262:803-816

Laengle S, Modak NM, Merigo JM, Zurita G (2018) Twenty-five years of Group Decision and Negotiation: A bibliometric overview. Group Decis Negot 27:505-542

M. Lee S, Sung Rha J, Choi D, Noh Y (2013) Pressures affecting green supply chain performance. Manage Decis 51:1753-1768

Martínez-López FJ, Merigó JM, Valenzuela-Fernández L, Nicolás C (2018) Fifty years of the European Journal of Marketing: a bibliometric analysis. Eur J Marketing 52:439-468

Merigó JM, Cancino CA, Coronado F, Urbano D (2016) Academic research in innovation: a country analysis. Scientometrics 108:559-593

Merigó JM, Gil-Lafuente AM, Yager RR (2015) An overview of fuzzy research with bibliometric indicators. Appl Soft Comput 27:420-433

Merigó JM, Yang JB (2017) A bibliometric analysis of operations research and management science. Omega 73:37-48

Miemczyk J, Johnsen TE, Macquet M (2012) Sustainable purchasing and supply management: a structured literature review of definitions and measures at the dyad, chain and network levels. Supply Chain Manag 17:478-496

Mingers J, Xu F (2010) The drivers of citations in management science journals. Eur J Oper Res 205:422-430

Oliver RK, Webber MD (1982) Supply-chain management: logistics catches up with strategy. Outlook 5:42-47

Pilkington A, Liston-Heyes C (1999) Is production and operations management a discipline? A citation/co-citation study. Int J Oper Prod Man 19:7-20

Pritchard A (1969) Statistical bibliography or bibliometrics. J Doc 25:348-349

Rao P, Holt D (2005) Do green supply chains lead to competitiveness and economic performance? Int J Oper Prod Man 25:898-916

Sarkis J (2012) A boundaries and flows perspective of green supply chain management. Supply Chain Manag 17:202216

Seuring S, Müller M (2008) From a literature review to a conceptual framework for sustainable supply chain management. J Clean Prod 16:1699-1710

Shiau WL, Dwivedi YK, Tsai CH (2015) Supply chain management: exploring the intellectual structure. Scientometrics 105:215-230

Small H (1973) Co-citation in the scientific literature: A new measure of the relationship between two documents. J Assoc Inf Sci Tech 24:265-269

Srivastava SK (2007) Green supply-chain management: a state-of-the-art literature review. Int J Manag Rev 9:53-80

Thomé AMT, Scavarda A, Ceryno PS, Remmen A (2016) Sustainable new product development: a longitudinal review. Clean Techn Environ Policy 18:2195-2208

Tiwari S, Wee HM, Daryanto Y (2018) Big data analytics in supply chain management between 2010 and 2016 : Insights to industries. Comput Ind Eng 115:319-330

Tseng ML, Tan K, Chiu AS (2016) Identifying the competitive determinants of firms' green supply chain capabilities under uncertainty. Clean Techn Environ Policy 18:1247-1262 
Tsireme AI, Nikolaou EI, Georgantzis N, Tsagarakis KP (2012) The influence of environmental policy on the decisions of managers to adopt G-SCM practices. Clean Techn Environ Policy 14:953-964

Valenzuela LM, Merigó JM, Johnston WJ, Nicolas C, Jaramillo JF (2017) Thirty years of the Journal of Business \& Industrial Marketing: A bibliometric analysis. J Bus Ind Mark 32:1-17

Van Eck NJ, Waltman L (2010) Software survey: VOSviewer, a computer program for bibliometric mapping. Scientometrics 84:523-538

Wang Q, Yang Z, Yang Y, Long C, Li H (2014) A bibliometric analysis of research on the risk of engineering nanomaterials during 1999-2012. Sci Total Environ 473:483-489

White HD, McCain K (1989) Bibliometrics. Annual Review of Information Science and Technology 24:119-186.

White L, Smith H, Currie C (2011) OR in developing countries: A review. Eur J Oper Res 208:1-11

Wong C, Skipworth H, Godsell J, Achimugu N (2012) Towards a theory of supply chain alignment enablers: a systematic literature review. Supply Chain Manag 17:419-437

Zhao L, Deng J, Sun P, Liu J, Ji Y, Nakada N, ... Yang Y (2018) Nanomaterials for treating emerging contaminants in water by adsorption and photocatalysis: Systematic review and bibliometric analysis. Sci Total Environ 627:1253-1263 